Polley, Resoarch, and Extornal Affalre

WORKING PAPERS

Trade, Finanoe, and Industry

Technical Department

Latin America and the Caribbean

Regional Office

The World Bank

Fobruary 1991

WPS 590

\title{
The Domestic Financial Market and the Trade Liberalization Outcome \\ The Evidence from Sri Lanka
}

\author{
Premachandra Athukorala \\ and \\ Sarath Rajapatirana
}

The main finding of the study is that the domestic financial market plays a very significant role in the success or failure of trade liberalization. This was found to be the case in Sri Lanka during 1977-87. 


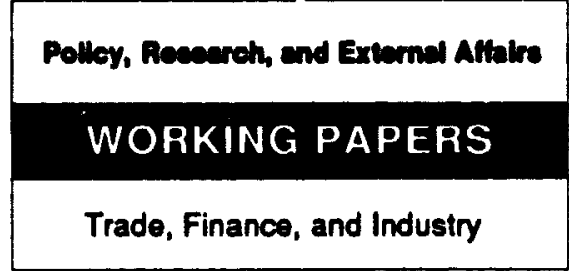

WPS 590

This paper - a product of the Trade, Finance, and Industry Division, Tectnical Department, Latin America and the Caribbean Regional Office - was undertaken as part of the World Bank's comparative study, Macroeconomic Policies: Crisis and Growth in the Long Run. Copies are available free from the World Bank, 1818 H Street NW, Washington DC 20433. Please contact Margaret Kienzle, room 14-058, extension 30733 (55 pages).

Athukorala and Rajapatirana developed a framework for analyzing the relationship between domestic financial markets and the effects of trade liberalization and applied it to Sri Lanka's experience between 1977 and 1987. They found that the domestic financial market significantly affects the outcome of trade liberalization.

Because Sri Lanka deregulated its interest rates when it undertook the trade liberalization, this allowed those eaming more from trade liberalization to hold financial assets rather than nontradables. The availability of savings and time deposits at attractive interest rates prevented the premature appreciation of the exchange rate, thus helping to maintain the competitiveness stimulated by trade liberalization. By reforming interest rates, removing credit ceilings, and increasing competition among banks, Sri Lanka helped increase private sector savings - which could be reallocated to the tradable sector.

Unlike carlier studies on financial reform in Sri Lanka, this one finds that financial reforms have increased private savings in financial institutions, raised economywide financial intermediation ratios, and expanded credit to the private sector.

More important, Athukorala and Rajapatirana find a statistically significant relationship between the financial intermediation ratio and the real exchange rate.

Credit to the private sector had increased after reform of the financial sector, but its reallocation was inhibited by large fiscal deficits, inconsistent monetary policies, and increased intervention in the financial market. Through their negative effect on the real exchange rate, these interventions offset some of thr gains in competitiveness achieved through trade liberalization.

Athukorala and Rajapatirana find no cvidence of financial crowding out in Sri Lanka. 
Table of Contents

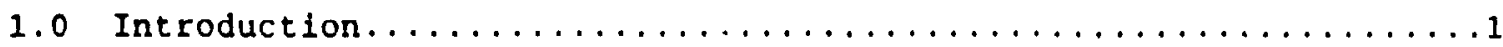

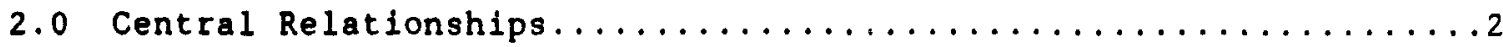

2.1 Demand Side Complementarity........................

2.2 Supply Side Complementarity.......................

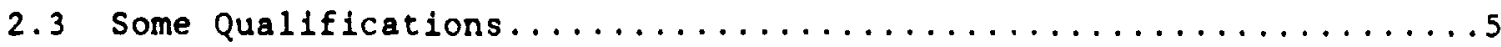

3.0 The Sri Lankan Setting $\ldots \ldots \ldots \ldots \ldots \ldots \ldots \ldots \ldots \ldots \ldots \ldots \ldots$

3.1 Key Elements of the 1977 Policy Reform................

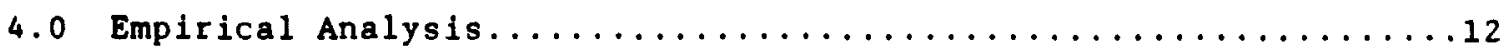

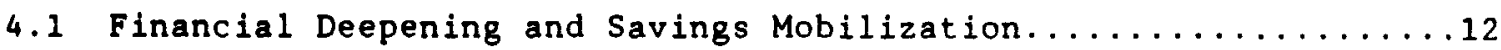

4.2 Financial Liberalization and the Real Exchange Rate..........14

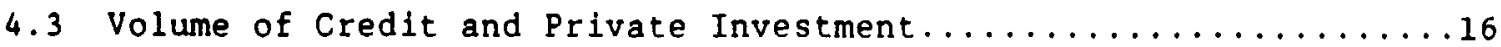

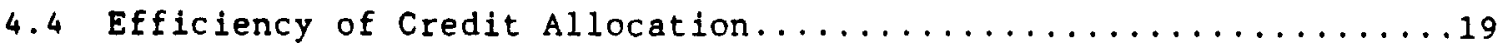

4.5 Financial Liberalization and the Informal Credit Market......21

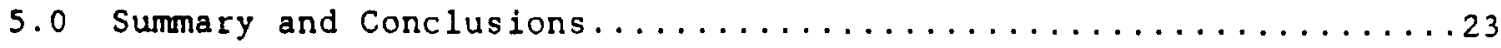

References...............................

Data Appendix.......................... $\ldots \ldots$

*The research done for this paper was undertaken as part of the Wild Bant: comparative study, "Macroeconomic Folicios. Sisis and Growth in the Lung Run," RPO 673-99. The authors wolld likp to thank vittorio Corhe and $W$. $M$. Tilakaratna for their very helptul. nmmonts an a draft proposal tor thic research. We would also like to thank leena lihatkhate for his iomments (') an earlier version of the papel and phillip Sawicki fol piliturial assistanis. 


\section{Introduction}

A sizable body of literature on the relationship between trade and development has appeared over the past two decades and has demoristrated that establishing a liberal trade regime is superior to a restrictive trade regime in achieving development objectives. This has led to a second wave of literature on trade liberalization--that is, on the issues involved in a shift away from a controlled (and hence, distorted) trade regime toward a more liberal one.

One such issue is the complementarity between trade reform and the operations of domestic financial markets. "Financial repression, "meaning policy distortions that interfere with efficient domestic financial

markets, is just as common in developing countries as policy distortions of the foreign trade regime. For many of these countries, "the liberalization of the foreign trade and financial sectors can be considered as two aspects of the same problem" (Mckinnon 1981:366). An unawareness of this complementarity may be one reason why many countries have opted for trade liberalization while continuing to intervene in the operations of their domestic financial markets.

The present study has two objectives. First, it presents a framework for analyzing the impact of the domestic financial environment on trade reform. Second, using this analytical framework, it examines the role of the domestic financial market in determining the fate of trade policy reforms initiated in Sri Lanka in 1977. Although generalizing from a single case has its pitfalls, the insight gained from the study may be useful to policymakers in other countries in identifying critical issues that may crop up in the process of designing and implementing similar policy reforms.

Sri Lanka was chosen to explore the hypothesized relationships because of both the nature of the reforms carried out there and the controversy surrounding the extent to which financial market reform contribute to the sustainability of trade reform. Some authors argue that the half-hearted nature of financial reform in Sri Lanka, combined with macroeconomic instability, was a major factor in reversing the 1977 policy of trade liberalization. (Lal and Rajapatirana, 1989; Hiemenz and Langhammer, 1989). Other authors (e.g., Jayawardena et al., 1987; Roo, 1982) have pointed to the Sri Lankan experience as an illustration of the harmful long-run consequences of setting interest rates "too high." In light of what happened during the first two post-reform years, for instance. Roe $(1982$, p. 218) argued that

the high interest rate provides a useful antiinflationary check in the short run and helps to moderate the speculative influences which could ctherwise have been stimulated hy Sri Lanka's trade liberalization. However, it is not a policy that should be looked to for significant long-term benefits. There is little evidence that the high interest rates are contributing to an improved allocation of capital funds. 
Coats and Khatkhate (1984) and Khatkhate (1988) consider Roe's analysis to be a "quite convincing" demonstration that $f$ reeing interest rates without regard for the real rate of return on investment may jeopardize the complementary relationship between financial asset accumulation and capital formation.

This study confines itself to the relationship between the domestic financial market and trade reform. In other words, it does not deal with the relationship between the capital eccount in the balance of payments and the trade liberalization. This latter issie has been extensively studied in recent years, and a consensus seems to have emerged that liberalization of the current account in the balance of payments should precede liberalization of the capital account in mos' circumstances $(e . g .$, Corbo, 1987; Edwards and Edwards, 1987; Frenke1, 1982; McKinrion, 1982).

Following established practice, the term "trade liberalization" as used here means "the process of removing, or reducing, the implicit premiums associated with quantitative restrictions (including rationing in the case of price controls) that prevent individuals from carrying out the transactions they wish to undertake at prevailing (world market) prices" (Krueger, 1985; see also Michaely et al., forthcoming; Choksi and Papageorgiou 1985). The term "financial liberalization" refers to any action to remove or reduce "financial repression" or "financial restriction." Financial repression occurs when the government orders interest rates to be set at rates well below those needed to balance the supply of financial savings with investment demand. Financial restriction occurs when expiicit or implicit taxes $(e . g .$, high reserve requirements, compulsory purchases of government securities, deposit taxes, prohibitions on lending to certain types of businesses, forced lending to bad risks) force banks to maintain a wide wedge between lending and borrowing, even if they are allowed to charge market rates (McKinnon, 1973; Shaw, 1973; Fry, 1988 ).

The rest of this paper is structured in the following manner. Section 2 surveys existing theory on how domestic financial market conditions affect the outcome of trade liberalization and delineates testable hypotheses. Section 3 outlines economic performance and financial development in the pre-reform Sri Lankan economy and describes the key elements of the 1977 trade policy reform. Section 4 attempts to sort out the ways in which financial market conditions affected Sri Lanka's economic adjustment following the trade liberalization. The implications of various policy initiatives in the financial arena as well as distortions which were left untouched in the process are analyzed in light of the earlier theoretical postulates. The final section gives a summary and the conclusions of the study.

\section{Central Relationships}

The otject of trade liberalization is to realize gains that can be made from a better allocation of domestic resources. In particular, the restructuring of incentives under trade liberalization is done in the belief that total factor productivity will be improved by eliminating discrimination against exports and efficient import substituting activities, reducing the variance in production incentives across 
industries, and encouraging a better allocation of resources to tradables. In coordination with trade liberalization, reform of domestic financial markets can play a crucial role on both the demand and supply sides. The demand side complementarity of the financial market involves appropriate adjustment of the real exchange rate (the relative price of traded to nontraded goods) following a trade liberalization. On the supply side, the domestic finance market influences factor mobility through its impact on both the volume and allocation of credit.

\subsection{Demand Side Complementarity}

The relative price adjustments which occur in an economy following trade liberalization can be expected to bring about a dep:eciation in the real exchange rate, thus encouraging a shift of resources to the production of tradables. Sustaining (and improving upon) this greater price competitiveness is necessary if the gains from liberalization are to be permanent.

Liberalization, however, usually will have favorable output and employment effects which may cause the real exchange rate to appreciate, thus counteracting the main goal of liberalization. That is. favorable expectations about income growth may be translated into greater perceived wealth, and greater perceived wealth may in turn be reflected in increased consumption if households change their savings levels with a view to achieving desired wealth targets in Metzlerian fashion. The level of investment may also increase, since liberalization generally raises the real return on investment. In the typical situation, this increase in aggregate demand will cause a deterioration of the current account and an appreciation in the real exchange rate. 1

A rise in domestic int-rest rates towaid market clearing levels, when it is one part of a financial reform package, may be an effective means of preventing premature appreciation of the exchange rate (Mckinnon, 1973; Kapur, 1986).2 An increase in interest rates raises the demand for interest-bearing bank deposits and reduces domestic nontradable prices for a given rate of money expansion and inherited set of inflationary expectations. A rise in domestic interest rates has the added advantage that it will produce an immediate increase in the volume of bank credit and thus may facilitate supply side adjustments. The use of contractionary monetary policy as an aiternative strategy for preventing a premature appreciation of the exchange rate may produce contractionary supply side

1. Under the usual assumption that tradables and nontradables are hoth normal goods, a rise in aggregate demand raises the demand fur loth types of goods. Since the economy is a pricetaker in the world market. the increase in demand for tradables is simply reflected as a trade deficit without generating any price rise. By contrast. increased demand for nontradables push up their prices as the supply is not perfectly elastic.

2. Here we of course assume that corscls or the capital account are not reiaxed. 
offects, given that business firms depend heavily on bank credit for working capital.

Interest rate reform may also have a favorable impact on the real exchange rate through its impact on the composition of asset portfolios. In most developing countries, the typical saver's (investor's) portfolio is composed mainly of direct financial claims (cash and bank deposits) and physical assets (mostiy real estate and related nontradables, and consumer durables). The market for indirect financial claims (such as bonds, common stocks, mortgages, commercial bills) is insignificant in most small country economies. Thus, if the financial regime remains repressed, the impact of an increase in income generated by trade liberalization wili lead to stronger demand for physical assets, particularly nontradables. Real estate is a typ.cal nontradable asset. Since property is in fixed supply. total holdings of financial assets and property are not altered by purchases of nontradables. The enhanced demand for physical assets will only stop when the price of property rises high enough to deter further purchases (Bevan et al., 1987). The outcome of this proc ss will be an appreciation in the real exchange rate which reduce the incentive to increase production of tradables.

\subsection{Supply Side Complementarity}

The typical pre-liberalization economy is one in which a variety of domestic markets, as well as the foreign trade regime, are subject to controls. As well as incurring significant economic costs individually, these controls interact with one another in a synergistic fashion to magnify their total cost to the economy (Krueger, 1984). In such a context, the manner in which the economy reacts to trade liberalization depends on what happens in related markets. Government control of these markets may severely constrain factor mobility, both by limiting the volume of credit and preventing its efficient allocation, thus reducing the intended benefits of trade liberalization.

A well-known feature of a repressed financial regime is the maintenance (If real incerest rates which are much less than the sum of the real rate of return on capital and the real resource costs of financial intermediation. Consequently, financial deepening is reduced, leading to a shrinking in the volume of institutional credit. This problem may be compounded if the government siphons away an increased proportion of institutional credit to finance its own investments. If that happens, the quality of the nation's investment portfolio and the capacity of the economy to generate surpluses may be compromised. The value of financial liberalization is that it augments the avdilability of investable funds, particularly for the private sectur, and thereby facilitates investment in the tradable sectors folluwing trade liberalization. : In a repressed financial regime, and owing to the resulting excess demand for institutional credit. credit is usuallv rationed on the basis of criteria unrelated to economic feasibility. credit rationing usually means making room in credit queues for projects that would automatically be disqualified if an equilibrium

3. It is generally the case that tradable sectors in most developing countries are dominated by the private sector. 
interest rate prevalleo. The invariable outcome is the allocation of some of che avallable credit for suboptimal projects while a larger number of high-return projects are denied credit.

There is another relationship between trade liberalization and the financial markets that should be noted. One of the purposes of trade liberalization is to raise the return on investments in the tradable sector. However, the sectors or firms to which the government channels credit are not necessarily associated with trade strategy priorities. Moreover, the cost of borrowing in a financially repressed economy can differ from sector to sector and may do so in a way that reduces the efficiency of resource allocation. Consequently, if the financial market is repressed, the anticipated reallocation of resources that should follow trade liberalizaiion may not take place or may take place in a less effective way.

There are two ways in which a controlled financial regine can thwart the employment and income distribution effects of trade lileralization. Credit rationing at artificially low interest rates, together with real exchange rate overvaluation and the preferential treatment accorded to capital goods imports in a controlled trade regime, encourages capitalintensive activities at the expense of labor-intensive activities (Krueger 1983). Furthermore, credit rationing may squeeze out small borrowers who cannot pay the high costs of obtaining information, who lack adequate collateral, or who are not likely to achieve economies scale. Small borrowers may also be denied credit because of the natural inclination of commercial private banks to favor only the largest and safest borrowers. (Gonzalez-Vega, 1984 and 1985). Reducing or eliminating credit rationing can therefore be expected to improve employment prospects and income distribution, since labor-intensive activity wiil benefit and a larger number of borrowers will have access to formal $\mathrm{cr}$

\subsection{Some Qualifications}

The hypotheses above focus only on the operations of che organized (formal) money market (OMM). In most developing countries, however, there is also an active but unorganized money market (UMM) often referred to as the "curb market" or "informal market." The volume of the lending transacted on this market may be at least as great as, and perhaps many times greater than, that of the OMM. ${ }^{4}$ Because of this, it has been argued that "financial liberalization is an exceedingly chancy proposition" in terms of whether it will produce financial deepening (Buffie. 1984:318, see also van Wijnbergen, 1382 and 1983: Bufcie. 1984: Taylor, 1983: and Edwards, 1988). Claims in the informal market may be an important alternative to holding transaction balances wash, and time deposits with commercial banks. These claims ale motly in the form of lirent hurrowing by households and thus can be termed "lon percent intermediation."

By contrast. reserve requirements nnstituto a leakage in the financial intermediation done through rommer:ial hanks. IBpause nf offi:ial roservo

4. Ghate (1988) provides a comprehensive sulv? of the literature on this phenomenon. 
requirements, bank lending based on household deposits implies a "(1-a) 100 percent intermediation" where " $a$ " is the reserve deposit ratio.) Given this difference, so the argument goes, financial liberalization may reduce the overall degree of financial intermediation of the economy, provided bank deposits are better substitutes for UMM claims than for cash. Van Wijnbergen (1982) and Edwards (1988) have provided empirical support for this hypothesis (now popularly known as the "financial crowding-out hypothesis"), using data from South Korea (henceforth, Korea).

The analytical value of this hypothesis for developing countries as a whole is yet to be established, however. The evidence of other authors (Little et al., 1987; Ghate, 1988; Fernando, 1988), in fact, suggests that any generalizations based on the Korean experience may be misleading. In Korea, "the UMM is largely an urban phenomenon" (van Wijnbergen 1982:124) and is "intertwined closely with the banking system, as funds raised by dealers in that market often pass through the banking system" (Kim 1986:151). It is therefore not unrealistic to treat UMM claims and commercial bank deposits as close substitutes. In other developing countries (except perhaps in Taiwan (Koshaka, 1984)], there is no such thing as "the informal credit market." Rather, there are many informal credit markets (distinguished by such factors as geographic location, type of lerder, and industry or service being financed) which operate independently of each other and with no links to the banking system. A significant portion of informal lending takes the form of noninterestbearing loans made on the basis of kinship, friendship, or patron/client relationships. And, given the high risk involved in the informal markets, most interest-bearing loans are made at rates that may be 5 to 10 times higher than market rates. Moreover, surveys suggest that resorting to the informal markets for investment and working capital is not typical of entrepreneurs in most countries, however common it may be in Korea (Little et al., 1987). It therefore seems reasonable to conclude that financial market reform is not likely to trigger a significant shift of funds from the informal to the formal market.

Another objection to the crowding out argument is that it assumes that a choicc is made by borrowers on the basis of monetary assets (cash, bank deposits, informal market claims) alone. Thus, the possibility of substitution of physical assets for financial assets, strongly emphasized by certain investigators (McKinnon, 1973: Galbis, 1977) is ignored. Glven the nature of household asset holding behavior in develoning countries, this substitution process may be of crucial importance in determining the outcome of financial market reform.

An increase in the volume of OMM transactions, even if it involves considerable crowding out of UMM activities, may be desirable on efficiency grounds. That is, a given quantity of savings mobilized via the formal financial sector may be more productive than the same quantity of savings molilized through informal channels. Eecause the supply of credit in curb markets is limited. money lenders in these malk its operate on a small scale and charge high interest rates. Concequently. borrowers use these funds mostly for short-term frojerts and for activitios where the potential 
competition for funding is low, as in the nontradable sector. 5 Given the high degree of variability of interest rates across informal markets and among different types of lending, "the main burden of ensuring that there is uniformity in borrowing rates and that competition is brcadly based rests with direct bank lending" (Shaw 1973:85).

\section{The Sri Lankan Setting}

After becoming an independent member of the British Commonwealth in 1948. Ceylon (as it was then commonly called) maintained an open trade reginie and a generally free domestic economy, but subsequent government decisions had practically closed the economy to the free flow of imports by the mid-1960s. ${ }^{6}$ By then, the Bank of Ceylon had been nationalized for five years and a state-owned commercial bank (The People's Bank) had been established to meet the financial needs of Ceylon's rurel areas. Aided by prohibitions on the opening of new branch offices by fcreign banks, and the opening of new accounts in foreign banks by Ceylon's inhabitants, the two state-controlled banks had grown rapidly. The financial sector was extremely repressed, and there was little room for independent and efficient financial intermediation (Khatkhate, 1982). The insurance industry had been nationalized in 1963, and large and growing percentages of the industrial, trade, and agricultural sectors were owned by inefficient state enterprises. The currency was highly overvalued, and most prices were stringently controlled.

Despite the steep $r$ ise in government intervention in the economy during the $1960 \mathrm{~s}$, Ceylon's economic growth was fairly respectable. The average annual rate of GDP growth during the decade was 4.5 percent, while average annual growth in per caoita income was 2.1 percent.

The period from 1970 to 1977 was marked by further government intervention in the economy and declining growth rates. In 1972 (the same year in which Ceylor. was formally renamed Sri Lanka), the government consolidated its control over the mobilization of household savings by setting up a National Savings Bank. By the mid-1970s, almost to percent of the total credit extended by al' financial market institutions was direct 1 ' absorbed for budgetary purposes (Lee, 1987), and the balance was rationed in favor of preferred institutions (mostly public corporations). With the enlarged conscription of funds from the banking system to finance public sector activities, the government succumbed to the temptation to set interest rates at low levels. Given continuing inflation (which had begun in the late $1960 \mathrm{~s}$ ), this produced negative real interest rates (Table 4 ).

The stock market stayed in the doldrums during the first half of the $1970 \mathrm{~s}$, with total share turnover declining to 2.5 million Rs. in 1975. compared with 19.8 million in 195:. (kalunatilake 1986). Constraints on foreign exchange remittances discuaded fotoign-(rined companies from buying

5. One way of saying this is that the a tivities of the informal soctor are less contestable as it is holeft if foreign competition.

6. For details on Sri Lanka's trade and de\%elument policy since independence see Rajapatirana 1988 , and the woks cited thelein. 
or selling the shares they owned, while threats of nationalization prevented the incorporation of new companies. Meanwhile, about one in every five Sri Lankan workers was unemployed.

Pervasive restrictions on the financial system had produced a process of financial disintermediation. The degree of financial intermediation, as measured by the $M 2 / G N P$ ratio, declined or re.. ined stagnant in most years. In 1977 , this ratio was well below the level recorded in the early $1960 \mathrm{~s}$ (Khatkhate, 1982). In short, the financial sector was moriburd, and the two major state-owned banks held 82 percent in value) of all deposits in the banking system.

Average annual growth in GDP between 1970 and 1977 slumped to 3 percent (1.2 percent in per capita terms). By 1974, the share of GDP produced by the public sector had risen to 16.2 percent (Erom 5.7 percent in 1961), and nationalization of the tea, rutber, and coconut plantations had raised this above 20 percent by 1977 . The country's legendary ability to give its people a higher standard of living was rapidly disappearing.

\subsection{Key Elements of the 1977 Policy Reform ${ }^{7}$}

Consternation over economic stagnation set the stage for marketoriented policy reform in 1977: trade liberalization, a significant exchange rate realignment, new incentives for foreign investors, overhaul of financial markets, limits on public sector participation in the economy, and the removal of price controls and government moncpolies in domestic trade. Half-heartedness and inconsistencies characterized the implementation of the new policies, but their mere existence marked a clear departure from the conventional wisdom of the closed eccnomy era.

\section{Trade Policy Reform}

Trade policy reform was the key element in 1977. Sri Lanka's quantitative restrictions on imports were supplanted by a revised system of tariffs, and this far-reaching change was accompanied by the removal of most of the price controls on domestic trade. While many of the tariff changes involved a gazetted increase in the rate, the degree of protection provided previously by way of licensing was significantly reduced. Some 280 items $^{8}$ remained under license, but for the most part licenses were issued freely. Subsequent measures in this area were of a corrective $k$ ind. A few items whose free importation had "damaging" impact on public enterprises were returned to the licensing list, and certain tariff rates were increased from time to time to increase revenues. The average effective rate of protection for the manufacturing sector increased

7. Elements of the 1977 policy reform package and its implementation. particularly the trade reform and its consequences, have been examined in detail elsewhere (Lal and Rajapatirana 1989: Cuthbertson and Athukorala 1900).

8. These items together accounted fin abnut \& percent of import value in 1980 (a "normal" year following lilelalization) (cuthbertson and Athukorala, 199n). 
marginally (by 3 percent) between 1978 and 1984 , but at the same time the average degree of dispersion of sectoral protection declined by about 6 gercent.

The opening up of the economy was 1 imited to current account transactions. While restrictions on renitting investment income or the proceeds of sales of assets by foreign firms were removed, the prohibition on overseas capital transactions by Srl Lankan citizens remained intact.

To supplement import liberalization, the dual exchange rate system introduced in 1968 was abolished, and the new unified rate was placed under a managed float. This resulted in an initial devaluation of almost 100 percent. The cumulative effect of trade and exchange rate reform was quickly reflected in a significant improvement in the overall profitability of tradable production (Table 3 ).

\section{Financial Market Reforms}

The major emphasis in financial market reform involved interest rate policy. The bank rate was raised from 8.5 percent to 10 percent, and this was followed by a shorp increase in int rest rates on leposits at the government-owned National Saving Bank (NSB). Commercial banks followed suit (Table 4). By 1980, due to rising inflation, real interest rates again became negative.

The goverr.nent responded by increasing NSB rates once more, thus triggering a second round of increases by the commercial banks. Interest rates on deposits have been freely determined since then, with the Treasury bill rate serving as the lower limit and the deposit rates of the National Development Bank the upper 1 imit. 9 There is no direct interference by authorities in the determination of lending rates, however.

In the area of institutional reform, the prohibition on new roreign bant branch offices, which had been in place since 1961 was relaxed in 1979. By mid-1980, 14 foreign banks had opened branches in Colombo, bringing the total number of foreign banks operating in the country to 21 (Table 1). Another institutional measure authorized all commercial banks to operate Foreign Currency Banking Units (FCBUs). An FCBU is permitted to undertake offshore banking services (accepting deposits and grenting loans in designated foreign currencies) to nonresidents, commercial banks, free trade zone enterprises, and other residents approved by the Central Bank.

These developments in banking, and rapid expansion by finance corpanies, set the stage for some competition in deposit mobilization and interest rates. An active interbank market also emerged. However, these

9. The rates paid by major commercial banks have continued to be lower than NDB rates. Some of the newly opened foreign banks and almost all finance companies (privately owned deposit-taking institutions involved mairly in hire-purchase and leasing financing), however, pay rates higher than these rates. Major commercial banks are able to pay lower rates because they provide additional services to customers. 
developments reduced the preeminence of the two state-owned banks only marginally (Tables 1 and 2 ).

The most important policy initiative in the sphere of credit allocation was the termination of the Comprehensive Rural Credit Scheme, under which the Central Bank offered an interest rate subsidy and a 75 percent defaultage guarantee to commercial banks (mostly to the two state-owned banks) on cheap loans provided to the agricultural sector. It was expected chat ending the progran would encourage commercia: banks to become active in grantir.g agricultural credit (Sanderatne, 1989).10

These actions notwithstanding, initiatives on the credit supply side generally meant an intensification of covernment intervention rather than liberalization. Following the interest rate reform, for example, the Central 3ank intensified its intervention in credit allocation. The Medium and Long Term Credit Fund, a little-used 1963 scheme to refinance loans maturing in 3 to 15 years by commercial banks and development finance institutions (EFIs), was revised in 1979 with a view to directing resources into priority areas. Prior to this, the program had only two categories: development of agriculture, and "other." Under the revision, agricultural development was divided into four subcategories, and export-oriented projects were accorded priority. More elaborate operational procedures were set up, while final approval of each individual project was retained by the Central Bank. Refinancing allowed the lending bank a final margin of 4 percent, a lending rate below the market interest rate for similar loans.

Then, a National Development Bank was established by the government to provide project finance, equity funding, and refinancing to public and private enterprises in priority areas. The Central Bank plays a supportive role in the operation of the NDB by guaranteeing repayment of loans provided by HDB under a Small and Medium Industry loan scheme (SMI).

In 1985, the Central Bank launched a scheme to establish Regional Rural Development Banks (RRDBS) (which essentially took the form of regional outlets providing cheap credit). The goal was "to build a sound rural credit structure because the existing commercial tanks $i$ : the country were not granting an appropriate amount of credit to the rural sector" (Central Bank, 1985).

A National Credit. Plan had been introduced in 1981 as a way to monitor the expansion of credit to the private sector and to direct credit to fricrity areas. 11 Under this flan, the Central Bank allocated credit

10. Credit provided under this shemo a nunted for about 7 percent of tctal bant credit to the private sector hy the mid-1970s. The default rate had climbed close to 80 perient

11. There seems to have peon a sienifi ant "external" influence hehind these poliry initiatives of the Contral Eant. The RRDB scheme was modeled after a similar scheme in Inlia. mder the advice of an expert from the Reserve Bank of India Malhotra. 1084 and 1982 (published in $19891)$. The external influence an also be identified in the designing int inipd on next page 
among the banks by negotiation. There were no penalties for noncompliance, but the Central Bank tried to bring banks into line through "moral persuasion."

No attempt was made, however, to reduce the government's absorption of financial savings mobilized through the "captive" financial institutions. About 90 percent of the NDB's loan portfolio continued to take the form of investment in government securities, 12 and a similar pattern war observable in the operations of the government-managed provident fund (EPF) and insurance corporations.

\section{Accompanying Policies}

A major setback to the impl-mentation of policy reform occurred in the areas of exchange rate management, export promotion, and public sector enterprises. After about 1981, the Central Bank gradually intensified its intervention in the foreign exchange market to support the exchange rate of the rupee. The rupee then gradually appreciated in real terms, with adverse implications for tradable production (Table 3 ). The newly established Export Development Board then had little success in restoring incentive levels, since the financial incentives it could provide to exporters were miniscule compared with the massive disincentive of currency appreciation.

While a few loss-making public enterprises were either shifted to the private sector or closed down, many others continued to operate despite dismal performance and ongoing dependence on budgetary transfers. Further, a number of ccrporations continued to receive preferential treatment. including high tariffs and quota protection (Cuthbertson and Athukorala, 1990). During the period 1977-85, almost 25 percent of total annual budgetary expenditures took the form of transfers to public enterprises. The comparable figure for the period $1970-76$ was only 10 percent.

The chief constraint to the realization of gains from economic liberalization, however, was the macroeconomic instability generated by a massive public investment program that included a billion-dollar multipurpose irrigation project (the Mahaweli Development Program, or MDP), a large public housing program, and an urban development program.

Between 1978 and 1982, these three projects absorbed about 75 percent of public investment, the Mahaweli project alone accounting for 45 percent. The imports needed for the projects were largely financed by aid donors. but the pressure on the government budget to provide counterpart funds was substantial. Thus, the projects put pressure on the government's ability

(continued from previous page) of the Export Crecit Insurance Corporation and various export-credit schemes of the Central Bank.

12. Investment in government securities carried an interest rate of about 10 percent as compared with the NSE deposit rates of 11 to 18 percent. The loss to the NSB resulted from this difference was covered by a subsidy from the treasury. 
t" maintain mavoronomio stalility. The direct expenditure effects of the pwions. aupled with inflationary pressure that criginated in deficit tinan ing. intributed $\rightarrow$ an apreciation of the real exchange rate with adverse impli:ations for the tradable goods sector. Macroconomic instability then womplled the government to take some policy stefs which ran cunter to the 1970 reforms. For instance, import duties were ingessi from time to time for revenue purposes, with adverse protective effects. Credit ceilings, and higher reserve requirement ratios on commerial lank leposits. produced a credit crunch which negated the ant i ilated tavoralle supply side effects of financial reform. Finally, intlationaly prossutes generated $r y$ the fublic investment program shriveled erided real interest rates, with adverse implications for savings molilization.

\section{Empirical Analysis}

To set the stage in applying the above framework, it is necessary to assess the impact of reform on financial deepening. Then, an attempt is made to trace the connection between the new financial regime and the uutcome of trade literalization. This is followed by an examination of the impa t of financial policies on the availability and distribution of loanalle funds, with emphasis on the implications for private-sector investment. In particular, changes in the interest rate structure and sotoral allocation ot credit are examined with a view to identifying the impliations of the financial regime on expected efficiency gains from trade liberalization. Finally, the findings of the previous sections are ceconsideted in light of the neo-structuralist emphas is on the crowding out ettel of inamial reform on the curt maket.

\section{- I Einanial Deepening and Savings Mobilization}

Easil indicatis of the finanilal depth of the economy are presented in Talle E. It is evident that interest rate reform in 1977 was followed by a ienakkalle improvement in financial intermediation. The M3/GDP ratio rose from an average level of 29 percent in the $1970-77$ period to 34 percent in 1079 ans statilized at around 40 percent in the $1980-87$ period. While MI

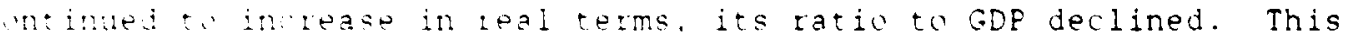
lattwa suggests a shift in husehold ascet fortfolios from cash holdings t" saving and time deposits (STDS) in response to favorable interest rates. To examine the role of interest rate changes in determining the pattern of tinan.ial intermediation, we pstimated demand functions for Ml and STD.

The explanatwy variables used in each equation were real GDF to represent

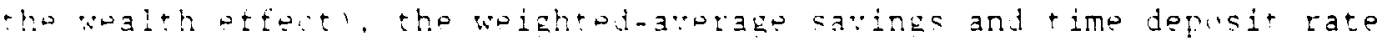

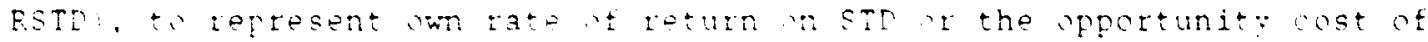

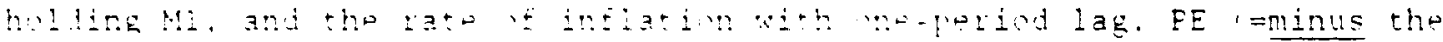

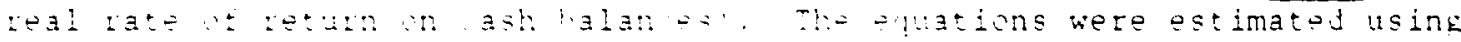

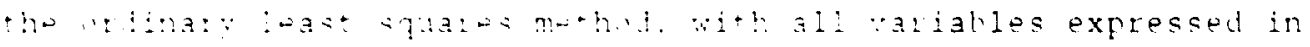

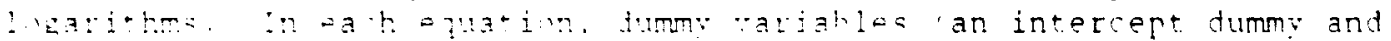

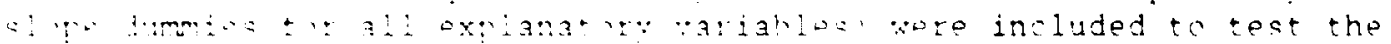

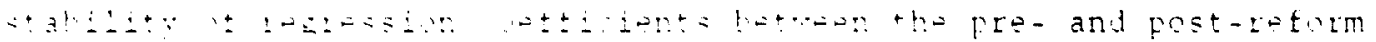

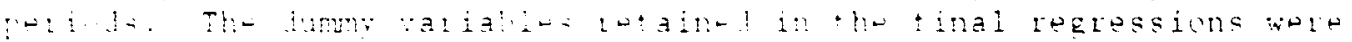

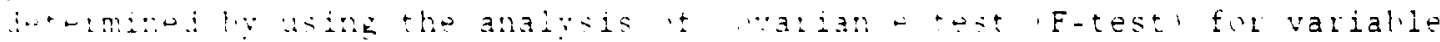

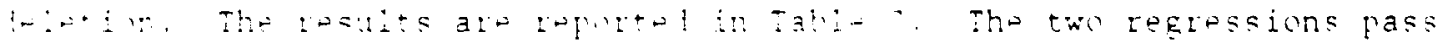

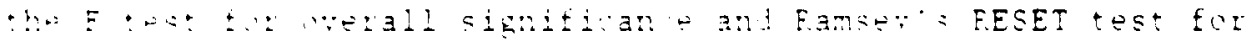


appropriateness of functional form. (The basic assumptions relating to the OLS error process were amply supported by various test statistics.)

The result for the RSTD variable in both equations suggests that individual financlal asset-holding behavior strongly depends on the rate of return on bank deposits. For the post- reform period (1978-87), a one percent increase in RSTD seems to have been associated with a 0.8 percent decline in real cash holdings and a 4.2 percent increase in real RSTD. The equation for STD showed a significant wealth effect operating upon financial savings behavior; a one-percent change in GDP was associated with a 1.5 percent change in STD. This effect on demand for MI was also statistically significant, but much smaller ( 0.5 percent). In sum, portfolio shifts (both from cash balances and other assets) triggered by interest rate policy were behind the surge in bank deposits (and hence the degree of financial intermediation), while the weaith effect generated by liberalization-led income growth seems to have played an important but secondary role.

Was the growth of financial savings reflected in an increase in the level of total domestic savings? According to the Mckinnon-Shaw thesis, a positive link between interest rates and financial savings also implies a positive link between the former and total domestic savings (investment), for at least two reasons. First, according to Mckinnon's "complementarity hypothesis" in a developing country context, a decision to accumulate financial savings is coterminous with a decision to acquire physical capital. Second, given limited portfolio choices, the savings process in these countries tends to be highly "money intensive" (Mckinnon, 1976). A contrary view is expressed by the neo-structuralists, who argue that while raising the rate of return on bank deposits is likely to induce a portfolio shift in favor of that asset, such a response need not reflect more savings but simply a decline in other assets (Taylor, 1988).

Jayawardena et al. (1987) interpret the Sri Lankan experience as supportive of the neo-structuralist position. Despite the impressive growth of bank deposits, there was "little evidence of any"significant mobilization of domestic savings" ( $p .27)$. But the data reported in Table 8 suggest that this observation, based on an analysis of data on total domestic savings, is misleading. During this period, public sector savings performance did not show any improvement, indicating the country's heavy dependence on foreign aid. Nonetheless, the behavior of private savings was an impressive improvement over the pre-reform period. For instance. the average propensity to save (the private savings to private imome ratio, or PRS/YPR) increased from 14.4 porrent in the $1970-7 h$ porind to 20.2 percent in the 1977-84 perind. Ecrnmetri. wnrk (Athukorala and

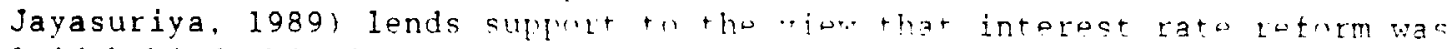
laid behind this improvement. Those octimatos suggest an intelest late

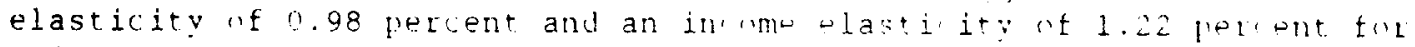
private savings. In sum, when the analvis is appropriately funcod on private savings behavion, the $s_{1}$ i Lankan xpit in provides ample culput for the Mckinnon-Shaw wiow pint, l'?

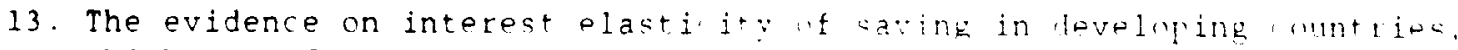

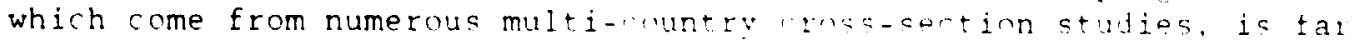

(continued in next page) 


\subsection{Financial Liberalization and the Real Exchange Rate}

In section 2, we presented the theoretical case for expecting complementarity, operating $v i a$ the real exchange rate, between financial liberalization and the outcome of trade liberalization. In particular, it was postulated that financial deepening would help sustain depreciation in the real exchange rate by containing aggregate demand pressure and by tilting household asset demand away from nontradable assets and towards interest-bearing bank deposits.

The empirical evidence presented in the previous section showed that both financial savings and total private savings responded favorably to interest rate reform. This evidence, in turn, supports the view that interest rate reform was instrumental in dampening the impact on nontraded goods prices of the surge in private income (expenditure) triggered by trade reform. In the absence of high interest rates, the expansion of domestic demand would have been stronger, and thus would have created greater pressure to push the real exchange rate upward.

Any attempt to make a detailed analysis of the impact of interest rate policy on household asset-holding behavior was hampered by an absence of time series data. Nevertheless, data from the Consumer Finances Survey of the Central Bank provide some support for our hypothesis (Table 9). Bank deposits as a share of household asset portfolios reached 33 percent in 1981-82, as compared with a historical figure of less than 10 percent.14

(continued from previous page)

from clear. (see Fry, 1989, Gonzales-Arrieta, 1988 for surveys of this literature). While some studies come down against any interest rate effect on savings, the others find a positive but rather small interest elasticity (around 0.1 percentage point) which is "not. large enough to warrant great policy significance" (Fry, 1989, p.20). The appropriateness of the multi-country cross-section approach (which implicitly assume that the observations are drawn from a "homogenous universe") to measure the average saving propensity for a diverse group of countries is, however. highly questionalle. The few available country studies (eg. onis and piedel 1989. iusuf and kyle-feters, 1984) have, in fact. produced intorost olasti-ity estimates which are similat in magnitude to our estimate tor Sri Lanka.

14. The mild decline in this share in $1978-70$ as reflected in the survey tata is anmewhat puzzline. The contlal Bank ascribes this decline to - insumors rush th sat isfy their pont-up domand accumulated nver a long period of imfort lestrictiono, tal dulate consumer gocds. following the trade liberalization Contlal Eank. Consumer Finances Surve: 1978:70. Part 1, F. 1:1:. 
To ascertain the cumulative impact of financial deepening on the real exchange rate, we developed the following model and then used annual data for the period 1970-87:

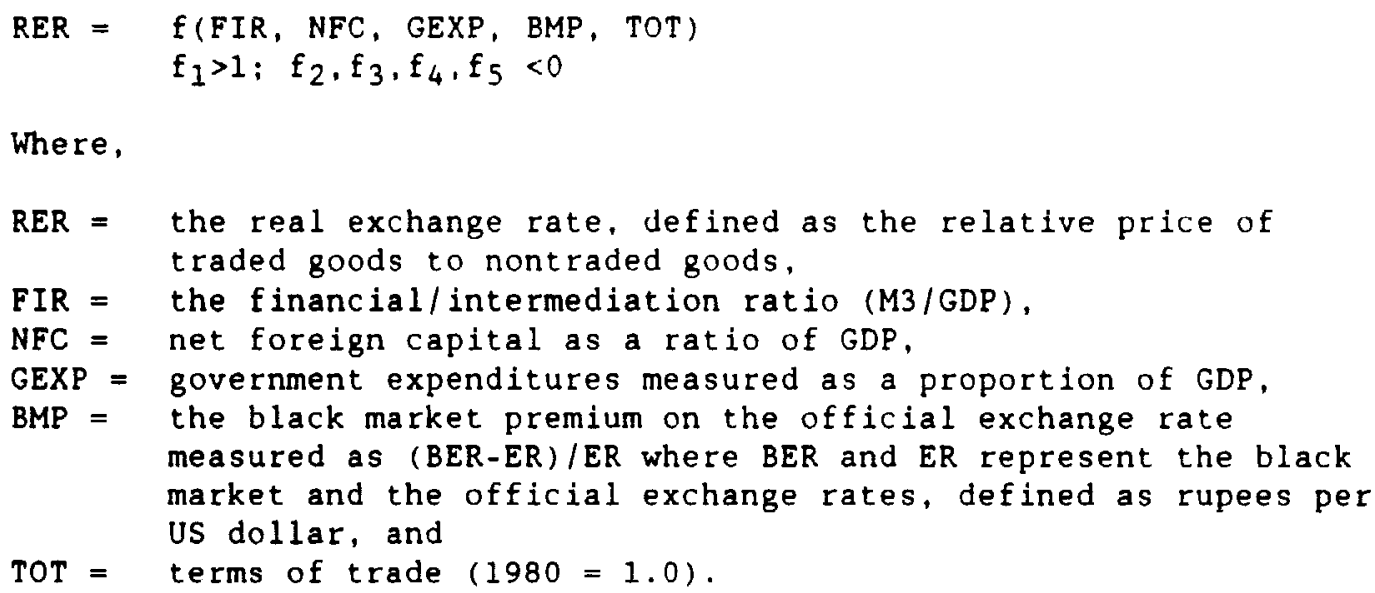

Because of the difficulties involved in directly measuring the prices of traded and nontraded goods, the real exchange rate is usually proxied by the nominal exchange rate, adjusted for change in the weighted average of the wholesale price indexes of trading partners relative to the domestic consumer price index (e.g., Edwards, 1988: Favaro and Spiller, 1989: Cottani and Garcia, 1989). This proxy measure is based on the (rather restrictive] "law of one price" assumption (Warr, 1986). In this study we measured the RER using implicit deflators derived directly from the national income accounts for tradable and nontradable production.

The degree of financial intermediation (the key regressor in the model) was represented by the M3/GDP ratio. The black market premium was included to capture the impact of government intervention on the real exchange rate. The expected effect of an overvalued exchange rate, of course, is that it tends to suppress the prices of tradables. Thus, we would expect a negative sign for the coefficient of this variable. The use of the other three variables is now standard procedure in determining the real exchange rate.

The model was estimated using the ordinary least squares method. As in the case of estimating money demand functions (Table 7), a dummy variable technique was employed to detect any structural break in the hrpothesized relationships that might have followed the 1977 reforms. On $1 \mathrm{v}$ the slope dummy for FIR was found to he immotant. Ther was high collineality between TOT. and NFC and GEXF. and ext lusion if the former implo... the statistical significanre uf the noffi, innt = it the latter two valialloc The results are reportel in Talle 1"!

The coefticiont of FIF was nut ctaticti ally significant for thr periof 1970-77. Eut it was highly signitilan $\because$ ith the oxperted sign tur thw

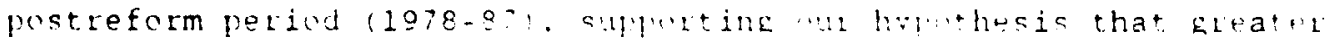

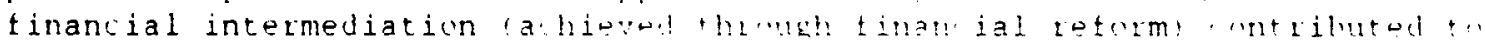
improvement in the competitivenos ut tralahlo productinn. Wo suspet that the failure of cur model to detert a sinnificant relationship letween R.EF 
and FIR during the pre-reform period was due to purely statistical reasons. First, our RER series might not have been a satisfactory indicator of real exchange rate behavior in an economy characterized by quantitative restrictions (QRs). In the presence of $Q R s$, the distinction between traded and nontraded goods becomes blurred; commodities subject to QRs are usually priced not on the basis of the prices of competitive imports but on the basis of domestic demand and supply (as in the case of nontradables) (Corden, 1987). Second, the degree of year-to-year variability of both data series was rather small. Given this "insufficient" variability, our regiession exercise may have falled to distinguish the effect of the FIR on the RER from other random effects on the latter. As we expected, both net foreign capital inflow (NFC) and government expenditures (GEXP) seem to have exerted significant downward pressure on the real exchange rate. By contrast, the coefficient of BMP was not statistically different from zero. This result supports the view that the real exchange rate is determined by real variables, and that therefore the nominal exchange rate has little influence upon it (Brock and Tower, 1986).

To sum up, our regression exercise provided a useful framework for understanding the behavior of the real exchange rate in Sri Lanka following the 1977 reforms. While interest rate reform had a notably salutary effect on the real exchange rate, this effect was crowded out by the much stronger combined negative effect of massive capital inflows and uncontrolled public expenditures. Consequently, the significant improvement in the country's international competitiveness achieved through trade liberalization was short-lived (Table 3 ). Had it not been for the favorable impact of increased financial deepening, che squeeze on the profitability of tradable producticn during the ensuing period would have been much sharper.

\subsection{Volume of Credit and Private Investment}

The increase in financial intermediation after reform (section 4.1) was reflected in a massive increase in the volume of institutional lending. Total real credit recorded a three-fold increase from Rs. 15.361 million in 1977 to Rs. 47.798 million in 1985 (Table 11). There was also a major shift in the allocation of credit in favor of the private sector. That sector's share increased from 28 percent in 1977 to 60 percent in 1985 , at the expense of the combined share of the government and public sector corporations. As noted above (section 3.2), financial reform did not include any measure to allow greater freedom for the portfolio decisions of government-owned nonbank financial institutions. Instead, these institutions continued to function as "captive sources" of budgetary finance. The increase in private sector credit therefore came predominantly from commercial banks. Reflecting the government's emphas is on guided credit to prinity sectns. ' lo lit oxtended by the development finance institutions (CFIs) did incoass Talle 13 ), but their share of total irstitutional credit allocated the private sector increased to only 7 percent by 1985 . In that veat. commercial banks accounted for 85 
percent of such credit, with the balance coming mostly from finance companies. 15

Expansion of institutional credit was undoubtedly a factor in the expansion of private sector investment in the postreform economy. Private fixed investment as a share of GDP increased from an average leve 1 of 8.5 percent in the early $1970 \mathrm{~s}$ to 18 percent in 1978-82 (Table 15). Between these two periods, the share of fixed investment in private-sector income rose from 10 percent to 18 percent.

To delineate the link between institutional credit and private fixed investment (PRW), an investment function was estimated using annual data for the period 1960-82.16 The explanatory variables were total real (1980) institutional credit to the private sector (ICP), the real GDP growth rate estimated in terms of logarithmic differences (YR), real public sector fixed investment (PBIV), an index of rental cost of capital (RC), 17 and PRIV with a one-year lag (PRIV(-1)). The inclusion of $Y R$ as an explanatory variable implied an accelerator-type relationship between the level of domestic economic activity and capital formation. PBIV was chosen as an explanatory variable in light of the debate on the crowding out effect (Blejer and Khan, 1984). PRIV(-1) was included as a regressor on grounds that the adjustment of actual investment to the desired level is not completed within a single period.

The estimated investment function is.

1n PRIV $=-0.33+0.63$ in ICP -0.34 in $\operatorname{PBIV}(-1)$

$$
\begin{aligned}
& (0.25)(3.52) * \quad(2.26) \star \star \\
& +0.05 \ln (1+\mathrm{YR})-0.07 \mathrm{ln} \mathrm{RC}+0.71 \mathrm{ln} \operatorname{PRIV}(-1) \\
& (3.14) * \quad(1.17) \quad(4.73) \text { * }
\end{aligned}
$$

$R^{2}=0.92 \quad F=49.3 \quad L M=0.02$

RESET2 $=0.03 \quad \mathrm{JB}=0.96 \quad \mathrm{WH}=0.85$

15. Estimated using figures obtained from. Central Bank, Review of the Economy. Figures used in the remainder of this paper, unless otherwise stated, come from this source.

16. The Central Bank has stopped publishing a ceparate private investment series since 1983.

17. This index is constructed as $R C=[\mathrm{FIM} *(1+\mathrm{NLR}) / \mathrm{P}] 100$

where PIM = lprice of investment goods proxied by the import frice index of investment goods $(1080=100$ (ac) $)$ usted for the dual exchange rate (FEEC) premium for the period $1958-7 ; 1$. NLP = nominal one-year (maximum) lending rate of commerial lanks and $F=$ implicit GDP deflator $(1980=100)$ for non-service a tivities. 


\section{Notes}

(1) t-ratios are given in parentheses, with level of significance denoted as $*=1 \%$ and $* *=5 \%$.

(2) For definitions of test statistics, see note 1 to Table 7.

According to the regression results, the short-run (one-year) elasticity of real private investment with respect to loanable funds was 0.63 . This figure, when combined with the coefficient of the lagged dependent variable, yields a long-run elasticity estimate of 2.17 . Thus, the hypothesis that private investment depends crucially on the availability of credit is supported overwhelmingly. The results also support the hypotheses on the positive impact of income growth and the negative impact (the crowding out effect) of public sector investment on private investment. But these influences seem much less important in magnitude as compared with the impact of credit availability. The coefficient of $R C$ is not statistically different from zero. From the use of the available data, there is no statistical support for the statement that "nigher interest rates and the high cost of investment appear to have inhibited private investment activity" (Jayawardena et a1., 1987:29; see also Roe, 1982). Ideally, one would have compared the rate of interest and the marginal efficiency of capital to test whether high interest rates inhibited investment. But in the absence of estimates for the marginal efficiency of capital it was necessary to estimate the specific investment function.

Commenting on the Sri Lankan finance market liberalization from a neostructuralist perspective, Rue (1982:248) noted that deposit interest rates were much higher "than the underlying productivity of the economy's capital will allow." But the regression results reported above do not accord with that view, which can also be disputed on other grounds. First, the empirical basis for Roe's view came flom estimates of return on capital (which vary from 5 to 10 percent) for public sector corporations. Our estimates of profitability for a sample of $\mathrm{pl}$. Iic limiter liability companies in the private sector, however, present an entirely different picture (Table 16). Second, it is inappropriate in any case to make a judgment about the desirable interest rate on the basis of a profitability estimate coming from the previous controlled trade regime, since the forces set in motion by liberalization would be expected to improve the profitability of investment. According to both macro-level and firm-level data (Tables 3 and 16 ), the profitability of private sector production improved remarkably following the trade reforms. As has been discussed in detail elsewhere (Cuthbertson and Athukorala, 1990). it was inconsistencies in the overall policy package which caused the improvement in profitability (particularly that of traded goods) to deteriolate afterwards. Third, as the experience of the ensuing years clearly indicates. the increase in the cost of credit cannot be ascribed entirely to higher ceposit rates. The interest rate spread tended to widen in the early $1980 \mathrm{~s}$ (Table 4). reflecting the impact of cther factors. including the increased 
restrictiveness in monetary policy, 18 high inflation, a new business turnover tax on interbank transactions, and the mounting operational costs of government-owned banks (see Lindrer et al., 1986, and Datta, 1983, for details). Finally, as noted above, even though total credit to the private sector increased considerably, the government continued to utilize well over a third of total institutional savings through its authority over nonbank financial institutions. The interest rate outcome would have been different if measures had been taken to redress this compartmentalization in the financial markets.

\subsection{Efficiency of Credit Allocation}

The analysis in the previous section provides empirical support for the $v$ iew that $f$ inancial reform, by augmenting the volume of institutional credit, played an important role in facilitating supply-side adjustment in the economy. This section extends that analysis by focusing on the pattern of credit allocation. In light of the theoretical discussion in section 2 , we focus on two aspects of the credit allocation process, namely, borrowers' access to institutional credit and the degree of dispersion in the cost of credit for various types of borrowing.

There are no time series data on the distribution of institutional credit at the firm level. The available survey-based evidence, however, points to an increase in the number of recipients of credit from the banking system. For instance, in a comparison of the financial structure of small-scale enterprises in 1977 and 1986. Islam and Romijn (1988) found that the percentage of firms which had obtained financial support during the period fror the banking system increased from 13 percent to 24 percent. The findings of the Consumer Finances Survey of the Central Bank relating to the distribution of household borrowing by source are consistent with this pattern (Table 17). According to this source, the institutional share in total household borrowing increased from 20.2 percent in 1973 to 25.3 percent in 1978-79 and 40.1 percent in 1981-2. This overall increase occurred despite the shrinking of subsidized institutional lending to the agricultural sector following the termination of the comprehensive credit scheme.19 At the disaggregated level, the sharpest increase occurred in borrowing for industrial activities. There does not seem to have been a rapid increase, as is popularly alleged, in borrowing for consumption. As theory predicts, various elements of financial reform, such as the greater availability of loanable funds, removal of credit rationing, and a more flexible interest rate structure might have contributed to the increased availability of institutional credit. Whatever the underlying reason may

18. The level of statutory reserve requirement on commercial bank deposit was increased in mid-1981 and aga in in November 1983, in response to aggravating macroecnnomic imbalance in the economy.. As a result. the weighted average of reserve requirement on all deposits increased from $7.4 \%$ to $8.1 \%$ in 1981 and $10.5^{\circ}$ in 1084 .

19. Following this step the share of agricultulal credit in total hank credit to private sector declined trom 15.2 percent in 1977 to 8.2 in 1982 . 
be, the broadening of the credit base may have been instrumental in improving employment prospects and income distribution.

Did financial reform, by reducing the degree of dispersion in the cost of credit. contribute to greater neutrality in the incentive structure of the economy? An in-depth analysis of this question is not possible, given the nature of the data base. There are no time-series data on lending rates or cost of credit on a sectoral basis. The only available data are those relating to the lowest and the highest lending rates of commercial banks and DFIs (Table 18). These data show that disparities in borrowing rates increased substantially (or else, the credit allocation in the economy became less efficient) after 1977. But it could also be that interest rate deregulation made it easier for less desirable borrowers to get institutional credit.

The lower rate for commercial bank lending, as well as all rates of the DEF and NDB, were usually those applicable to loans to sectors accorded priority under the "directed" credit policy. Given an annual inflation rate of 5 to 12 percent during this period, these rates implied a negative real cost of capital to preferred borrowers. By contrast, the upper (market-determined) rates remained highly positive. The structure of lending rates therefcre introduced credit market distortions and ran counter to the primary objective of trade liberalization--realizing gains from better allocation of resoures.

A major explanation for the wide gap between lending at favored or nonfavored rates seems to lie in the nature of the banking system itself. The opening of the banking system to foreign competition had only a marginal impact on the dominance of the two state-owned banks, in terms of both volume of transactions and extent of lending activities (Tables 1 and 2 ). The "old" foreign banks and the locally-owned private banks showed little interest in extending their operations beyond their traditional domain of trade financing, while the "new" foreign banks, were not eager to do business with purely domestic clients. The provision of long and medium-term finance $f$. industry and agriculture continued to be the role of the state-owned banks. Given the compartmentalized nature of lending, there was little competition in loan rates. Added to this, the state-owned banks continued to be under pressure to set lending priorities and interest lending rates with the government's policy priorities. Since these banks were also expected to be profit-making institutions, relatively low (and at times negative) interest rates for pricrity clients usually implied excessively high rates for on non-priority borrowers.

Administered priority lending was based on the premise that "high" market-determined rates might deter long-term investment in the tradable sector and thus jeopardize the sustainability of trade liberalization. 20 In liactice, however, apart from introducing a significant element of distortion into the economy. this guided credit policy achieved little. 1983. Lefinanced credit accounted for less than 5 percent of the total domestic loans uf commercial banks. and abuut two-thirds of this lending

This has been a recirrent theme in the annual financial-sector review in the Review of the Economy of the Central Bank. 
represented pre-export credit extended at a rate below the Treasury bill rate.

Despite policy rhetoric, the share of commercial bank credit allotted to the tradable sector relative to credit for the nontradable sector declined from about 1978 (Table 12). Accompanying this was a gradual decline in the combined share of medium and long-term credit in total bank lending.

The operation of DFJs was lackluster. An inspection of their lending records shows that they were not successful in allocating resources to priority sectors, particularly export-oriented industries. Their lending continued to be limited mainly to meeting the credit needs of a handful of established business groups with diversified interests. 21 This suggests that a large part of the credit subsidy was diverted into nonpriority sectors.

The failure of Sri Lanka's directed credit policy in the context of trade liberalization is a subject which needs further study. 22 However. the evidence considered so far supports the view that a directed credit policy is unlikely to be successful when the overall climate of incentives is moving in a different direction.

\subsection{Financial Liberalization and the Informal Credit Market: Some Observations}

So far, we have examined the implications of financial reform with respect to the formal money market (OMM). In this section we briefly consider whether our basic conclusions need to be qualified in 1 ight of the neo-structuralist crowding-out argument against financial liberalization (Section 2.3). A formal test of the crowding-out hypothesis is precluded by the absence of required time-series data. However, there is a

21. In a comparison of lists of client companies of NDB and DFC for 1984 we were able to detect 30 instances of the same client appearing in both lists. Most of these are well established import-substituting manufacturing firms with a long history of operation. Moreover, the DFC's sublist of large-scale clients for 1984 is not much different from a similar list for the mid-1970s. On the basis of a list of exporters (for 1984 ) prepared ly the Export Development Euad, we wero able to identify only about $10-15$ pount ot the client companies $n f$ DFC and NDB as exporters.

22. This issue is of particular interest given the recent concern about the need, in the context of the typi:al doveloping eccnomy where there is no well developed equity market. for a hiouing a proner halance petween the conflisting oljectivos of maintaining martet learing interost

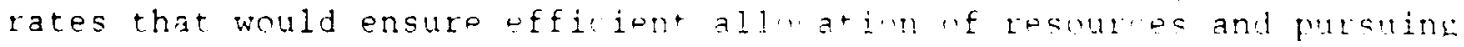

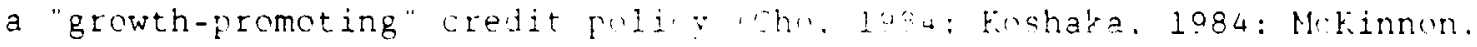
1988: Collier and Mayer, 1989). 
substantial body of survey-based evidence on informal credit markets in sri Lanka 23 which permits us to draw some inferences.

In Sri Lanka, as in many other developing countries (Ghate, 1988), the informal money market has continued to play a more important role than th? formal market in the provision of credit. 24 In 1981-82, for instance, almost 60 percent of the household borrowing in Sri Lanka (which includes borrowing by informal businesses and cottage industries) was provided by the UMM (Table 17). According to a mid-1970s survey of the informal sector in Colombo, over 75 percent of the credit granted to informal businesses came from informal sources (Marga Institute, 1978 and 1981). Informal sources of credit are by no means confined to households and small businesses. The Pettah Money Market (the informal money market in Colombo) is believed to handle very large volumes of funis (Sanderatne, 1989; Datta, 1983). However, the mere existence of a sizable UMM does not necessarily imply significant crowding-out following reforms in the OMM. This will occur only if the UMM is "competitive and agile" (Taylor, 1983), and if it. is closely linked with the OMM so that bank deposits are a better substitute for UMM claims than cash or other assets. As argued in Section 2.3. such a characterization may be incorrect in the typical developing country. In fact, the competition and agility is restricted to limited areas and groups. The evidence from Sri Lanka further illustrates this point.

One of the important facts shown by this evidence is that "informal lending consists of a wide range of sources and arrangements, in contrast to the general tendency to think of informal credit as synonymous with pure money lending" (Sanderatne, 1989:22). The share of pure money lenders in the total informal borrowing of households seems to be only about 24 percent (Table 17). A larger share ( 31 percen:) comes from friends and relatives in the form of reciprocal transactions. The rest ( 55 percent) is mostly a part of land tenure relations and the systems of produce marketing and consumer credit. Under these credit arrangements, the lender usually has a vested interest in the borrower's economic activity which extends beyond interest income.

The view that the informal financial market is segmented, noncompetitive, and not well integrated with the formal market, is further supported by data on the interest rate structure of informal credit (Table 19). According to the data, nearly 50 percent of such credit is granted either free of interest or at interest rates which are much lower than those of institutional credit. Given the absence of directly observable interest rates in kinship and patron-client relationships, it is difficult to compare the terms of credit in the informal market with those of institutional credit. Howevel. the lull (N) 85 percent) of the (credit supplied by moneylenders is extended at wory high interest rates. It therefore seoms unlikel that even a dract i change in institutional

23. Fernando (1988) and sanderatno (1088 and 1889) provide useful syntheses if this literature.

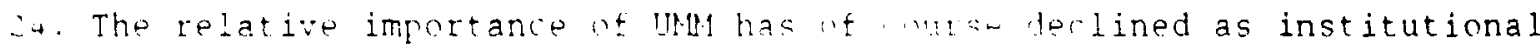
londing increased (Table 171 . 
interest rates has an impact on the volume of informal credit. This is perhaps because the financial technologies to sirve different clients also vary very much.

In the informal financial system. moneylenders rarely act as Intermedlaries between savers and investors (Sanderatne, 1989; Bouman, 1984). Moneylending has been characterized as unsocial and exploitative in Srl Lanka. Hence, the activity of moneylenders is often clandestine and restricted to known persons. Moneylenders usually operate with their own funds, and the average saver rarely considers them an alternative source of saving.

Data relating to the purpose-wise distribution of informal lending also indicate that it is predominantly obtained for so-called nonproductive purposes, such as family ceremonies and emergencies. Formal sector financial institutions seldom are willing to make loans for these purposes. On the other hand, the bulk of the credit used for agricultural, industrial, and other productive activities does come from formal sources. For instance, according to a Central Bank survey of planned investment in the corporate sector. "other sources" (which includes informal borrowing) contributed less than 5 percent of the total financial needs of the corporate sector in 1983/85 (Central Bank, 1986). The Marga Institute survey cited above found that moneylenders provided only 1.3 percent of the total borrowings of informal sector businesses in Colombo.

In summary, Sri Lanka offers no evidence that funds flow freely and swiftly between formal and informal markets in response to interest rate differentials. It is therefore unlikely that the substitution from UMM would have been of significant magnitude to counterbalance the significant increase in institutional savings/lending that resulted from the substitution of bank deposits for currency holdings and real assets supplemented with the wealth effect on demand for financial assets following the 1977 reforms. 


\section{Summary and Conclusions}

\section{The analytical framework}

An analytical framework to assess the role of the domestic financial market in the outcome of trade liberalization outcome was developed and then applied to Sri Lanka's 1977 trade reform. At that time the domestic financial market was also reformed, reducing financial repression. The main finding of the study is that the domestic financial market plays a very significant role in the success of a trade liberalization.

In Sri Lanka's case, inancial sector reform helped to some extent to sustain the greater competitiveness of the tradable sector achieved through the trade liberalization. Financial reform, however, did not go far enough, and its implementation remained somewhat ambiguous. The emergence of large $\mathrm{fiscal}$ imbalances after 1982 ther. weakened the impetus for trade liberalization.

On the demand side, the domestic financial market made its impact on trade liberalization by way of the real exchange rate. A domestic financial market that offers financial assets with attractive rates of return affords an alternative to the spending of increased income from trade liberalization on nontradables. Premature appreciation of the exchange rate is thus averted. But high rates of return on financial assets can only be found in a nonrepressed domestic financial market. Morecrer, market determined interest rates will influence overall savings/investment decisions and restrain aggregate demand. This too will prevent premature appreciation of the :xchange rate by channeling increased real savings into investment and thus avoid the need to provide investment funds through money creation.

On the supply side, a nonrepressed domestic financial market can complement trade liberalization by facilitating increased investment in the tradable sector. Such a market will also lead to better channeling of credit for the increased production of tradables induced by a trade lilelalization.

\section{The Sri Lanka Case}

There were several reasons why the application of our theoretical framework to sri Larka made good sense. First. the 1977 trade

liheralization replaced nearly all the quantitative restrictions on imports with tariffs which reduced the le\%ol at and the variane in luctoction. and was a companiol by a strone doraluation. Sw.nly thero was a sharp

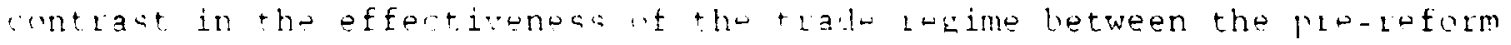

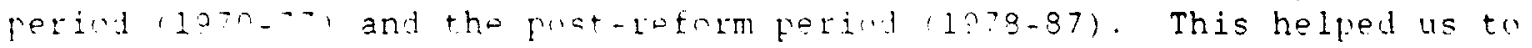
ildontify ko hanges in the trade rogimo. Thild. the fact that the capital ac nunt in the lalance of payments romainol rirtually closed to private

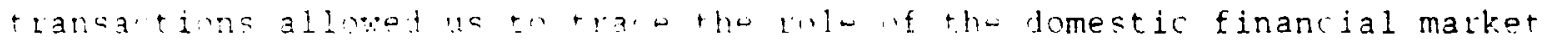
in lolatinn t" trade libelalization. Fonth. trale liberalization occurred at the same time that the sri Lankan anommon leregulatod the interest

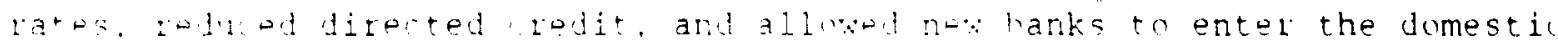
than lal matrot. Thus, the onif: $t 1: m$ a hithl: reprosed financial regime 
to a less repressed system enabled us to identify changes in the domestic financial market. Finally, the reliable and adequate data needed to perform econometric tests on the hypothese, suggested by the analytical framework was available.

\section{The Empirical Evidence}

Empirical analysis of trade liberalization and financial market reform yielded a number of interesting results.

First, as described above, trade liberalization is facilitated when financial intermediation becomes more extensive. More institutional credit becomes available to finance the desired fxpansion of the tradable sector. In Sri Lanka, the M3/GDP ratio rose from $29 \%$ in the $1970-77$ period to $34 \%$ in the 1980-87 period. The M1/GDP ratio declined after 1977, indicating a shift from cash to savings and time deposits in household asset portfolios. Econometric tests (using an OLS regression model) confirm a positive relationship between time and savings deposits and the interest rates paid on such deposits. Similarly, a negative relationship was found between interest rates and real cash holdings. For example, a one percent increase in savings and time deposits was associated with an $8 \%$ decline in real cash holdings and a $4.2 \%$ increase in the real interest rates paid on the deposits. The regressions also indicated a wealth effect. A one percent increase in real GDP was associated with a $1.5 \%$ increase in savings and time deposits. As hypothesized, a nonrepressed financial system led to a higher rate of domestic asset accumulation. That helped the trade liberalization by increasing the availability of institutional credit.

Second, there was also ample evidence to show that private savings responded positively to the increased real interest rates. There was an impressive improvement in the ratio of private savings to private income, from $14.4 \%$ in the $1970-76$ period to $20.2 \%$ in the $1977-84$ period. This increase in private savings can be interpreted as the response to a change in permanent income and the real interest rate. Econometric estimates suggest an interest elas'icity of $0.98 \%$ and an income elasticity of $1.22 \%$ for private savings. These results stand in contrast to the earlier work of others, which found no relationship between total domestic savings and interest rates. This is not surprising, since public sector savings are seldom correlated with interest rate changes. Besides, the large inflows of foreign capital to the public sector following the 1977 reforms implied negative public savings. Thus, to the extent that savings responded to interest rates, more noninflationary finance was available for investment.

Third, a relationship exists between the trade reform and the domestic financial market through the real exchange rate. To the extent that households increased their demand for tomestic financial assets rather than nontradables because of the increase in income from trade liberalization. appreciation of the real exchange rate was retarded. Thus, in the ahserce of attractive domestic financial assets and restrictions on holding foreign assets, the exchange rate would approsiate mose. Evidence from the consumer Finance and Sociceconomi surver in $s_{1} i$ Lanka indicates that household portfolios did shift toward lank depicits. the most attractive financial asset at the time, the chare hant loposits in household asset portfolios rising from a historical ration of $1 \%$ t.0 $3 \%$ in $1981-82$. 
Econometric tests were performed to investigate the cumulative effect of financial deepening on the real exchange rate. A regression model was estimated with the real exchange rate as the dependent variable: the model used the financial intermediation ratio and a number of other explanatory variables. The results indicate that the financial intermediation ratio was a highly significant determinant of the real exchange rate and showed the expected sign for the postreform period. The tests, however, failed to shuw such a relationship during the pre-reform period. This is perhaps to be expected, given that the real exchange rate could have been contaminated by the presence of import quotas. Moreover, the financial intermediation ratio remained low and constant over a long period up to 1977 , reflecting a high degree of financial repression.

The other variables used in the regression model, such as the exchange rate premium, government expenditures and terms of trade variations seem to have controlled the real exchange rate in the prereform period. Thus, the evidence confirmed the hypothesis that in the absence of financial reform, the 1977 trade liberalization would have been thwarted by an earlier and larger appreciation of the exchange rate. Financial reform helped to maintain the competitiveness gained from trade liberalization by providing attractive financial assets as an alternative to the purchase of nontradables.

Fourth, following the financial reform and the resulting rise in the financial intermediation ratio, real credit to the private sector increased threefold during the 1977-85 period. Given that the private sector produces and consumes relatively more tradables than the public sector, this may also have helped to delay appreciation of the exchange rate. This is because increased expenditure on tradables has no impact on the real exchange rate. Moreover, with the increase in real credit, private fixed investment rose from $8.5 \%$ of GDP in the early 1970 s to $18 \%$ in 1978-82. Regression results showed the elasticity of private direct investment with respect to real loanable funds to be $0.63 \%$ in the short term and $2.17 \%$ in the long run. Private investment in tre tradable sectors became more profitable after the trade liberalization, and this investment in turn was facilitated by the financial sector reforms that increased the availability of real luanable funds.

Finaliy, as indicated in the theoretical framework, an interest determined credit allocation enhances the shift of resources to the tradable sector following a trade liberalization and improve resource allocation. Conversely. the presence of directed credit in a repressed financial system stands in the way of credit flows to finance the expansion of the tradable sector. To the extent that directed credit would have favored large firms producing for the domestic market under a repressed financial system. increases in the allocation of credit to small-scale enterprises would provide scme support for the view that credit allocation improved following the reforms. Following the financial reforms, the ammunt of credit flowing to sinali enterplises in Sri Lanka doubled between 1977 and 1986. Howerer. evidence for improved credit allocation because of the dispersion of interest rates remains ambigunus. The dispersion of interoct rates increased following the trade and financial sector reforms. intrary to what is predictod by thor 2 . But some factors could help to explain the increased dispersion. The financial market reform may have 
given risky borrowers a better opportunity to obtain credit. On the other hand, the Central Bank continued to maintain differential discount rates and to subsidize credit for some purposes. This in turn tended to impede the competitiveness of the tradable sector gained through the 1977 trade liberalization. 
References

Athukorala, Premachandra (1981) "Import Substitution, Structural Transformation and Import Dependence--The Case of Sri Lanka" Developing Eccnomies. 24(1): $119-42$.

Bouman. F. J. A. (1984) "Informal Saving and Credit Arrangements in Developing Countries: Observations from Sri Lanka" in D. H. Graham and J. D. von Pischke (eds.) Undermining Rural Development with Cheap Credit, Boulder: Westriew. Ch. 19 .

Bevan, David. Arne Bigsten. Paul Collier and Jan W. Gunning (1987) East African Lessons on Economic Liberalization. Thames Essay 48 , Aldershot: Gower for the Trade Policy Research Centre.

Blejer, Maric I. and Mohs in S. Khan (1984) "Government Policy and Private Investment in Dereloping Countries" IMF Staff Papers, 31(2): 379-403.

Brock. Fhilip and Edward Tower (1986) "Economic Liberalization in Less Developed Countries: Guidelines from the Empirical Evidence and Clarification of the Theory," in M. Connolly and C. Gonzalez-Vega (eds.) Economic Reform and Stabilization in Lat in America, New York: Fraeger, $19-43$.

Buffie. E. F. (1984) "Financial Repression, the New Structuralists and Stabilization Policy in Semi Industrialized Economies, "Journal of Development Economics, 14(3): 305-22.

Central Bank of Sri Lanka (1984) Report on the 1985 Survey of Business Activities and Flanned Investments in Sri Lanka, 1982/3 to 1985/6. Colomio.

Cho, roon Je (1984) "Inefficiencies from Financial Liberalization in the Absence of Well Functioning Equities Markets" Journal of Money, Credit and Banking, $18(1)$

Cho. Fonn-Je and Deena khatkhate (1989) Lessons of Financial Liberalization in Asia: A Comparative Study. World Bank Discussion Papers No. 50. Washington. DC. World Bank.

Choksi. Armeane M. and Demetrios Fapageorgious (1986) Economic Liberalization in Developing Countrios. Oxford: Basil Elackwell.

Coats, Warren $L$, and Deena $F$. Fhatkhate 1984 "Monetary Folicy in Less Feveloped Countries: Main Issues. Fevelowing Economies. 22(4):329-48.

Collier. Faul and Colin Mayer (1989) "The Assessment: Financial Liheralizatian. Finanial systoms, and Economic Growth" Oxford Review of Ecuncmis Fulin. $511: 1-14$.

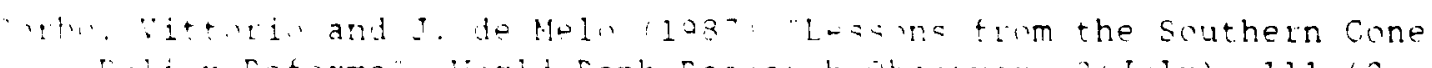

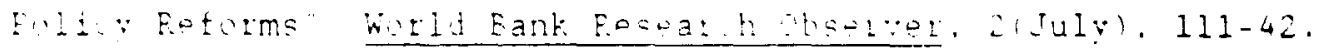


Corden, W. Max (1990) Exchange Rate Policy in Developing Countries, Policy, Research, and External Affairs Working Papers No. 412, Washington, DC: World Bank.

Cottani, Joaquin A. and Raul E. Garcia (1989) the Determinants of the Real Exchange Rate in Argentina, 1976-85, Washington, DC, World Bank (Brazil Department, unpublished manuscript).

Cuthbertson, Andrew G. and Premachandra Athukorala (1988) The Timing and Sequencing of Trade Liberalization Policies: Sri Lanka, Statistical Appendix (mimeo), Washington, DC: World Bank (Brazil Department).

Cuthbertson, Andrew G. and Premachandra Athukorala (1990) "Liberalizing Foreign Trade: the Experience of Sri Lanka" in A. M. Choksi, M. Michaely and D. Papageorgious (eds.) Liberalizing Foreign Trade: The Experience of Indonesia, Pakistan and Sri Lanka, Oxford: Basil Blackwell.

Datta, Gautam (1983) Sri Lanka: An Evaluation of the Financial system with Emphasis on its Role in Resource Allocation to Industry. Washington, DC: Country Policy Department, World Bank.

de Melo, Jaime and James Tybout (1986) "The Effects of Financial Liberalization on Savings and Investment in Uruguay" Economic Development and Cultural Change, 34(3): 561-87.

Edwards, Sebastian (1989) Real Exchange Rates Devaluation and Adjustment: Exchange Rate Policy in Developing Countries, Cambridge, Mass: MIT Press.

Edwards, Sebastian (1988) Financial Deregulation and Segmented Capital Markets: the Case of Korea, World Development, 16(1): 185-94.

Edwards, Sebastian and Alejandra C. Edwards (1987) Monetarism and Liberalization: The Chilean Experiment, Cambridge, Mass: Ballinger.

Favaro, Edgardo and Pablo T. Spiller (1989) The Determinants of the Real Exchange Rate in Post-Waw Uruguay, Washington, DC: World Bank (Brazil Department, published manuscript).

Fernando, Nimal A. (1988) "the Interest Rate Structure and Factors Affecting Interest Rate Determination in the Informal Rural Credit Market in Sri Lanka," Savings and Development. 12(3): 249-66.

Frenkel, Jacob (1982) "The Order of E'unmi Liholalization: Iisussion."

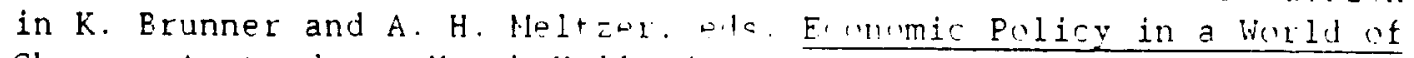
Change. Amsterdam: Huth Holland.

Fry. Maxwel1 J. (1988) Honey. Interest, and Eanling in Economi:Development. Baltimere. MD: Iohn: Hoplins Iniversity Plocs.

Fry, Maxwell J. (1989) "Financial Dumolurmunt: Therries and Pecent

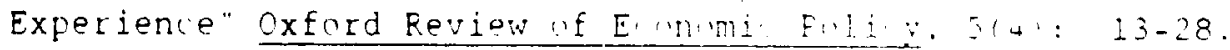


Ghate, P. B. (1988) "Informal Credit Markets in Asian Developing Countries" Asian Development Review, 6(1): 64-85.

Galbis, Vincent (1977) "Financial Intermediation and Economic Growth in Less Developed Countries: A Theoretical Approach" Journal of Development Studies, $13(2): 58-72$.

Gonzales-Arrieta, C. M. (1988) "Inter it Rates, Savings and Growth in LDCs: An Assessment of Recent Empirical Research, World Development, 16(5): $589-605$.

Gonzalez-Vega, Claudio (1984) "Credit Rationing Behavior of Agricultural Lenders: The Iron Law of Interest Rate Restrictions" in D. W. Adans and D. H. Graham (eds.) Undermining Rural Development with Cheap Credit Boulder, Colo: Westriew Press, 78-95.

Hiemenz, U. and R. L. Langhammer (1989) "Liberalization and the Successful Integration of Developing Economy" in G. T. Renshaw ed. Market Liberalization, Equity and Development, Geneva: ILO, $105-39$.

Islam, Rizwanul and Hendrika A. Romijn (1988) "Growth Performance and Potential of Rural Small-Scale Industries in a Liberalized Economic Regime: The Case of Sri Lanka" Marga, 9 (3\&4): 49-77 (Colombo).

Jayawardena, Lal, Anne Maasland and P. N. Radhakrishnan (1987)

Stabilization and Adjustment Policies and Programmes - Sri Lanka, Helsinki: World Institute for Development Economic Research.

Kapur, Basant K. (1986) Studies in Inflationary Dynamics: Financial Liberalization in Less Developed Countries, Singapore: Singapore University Press.

Khatkhate, Deena (1982) "Anatomy of Financial Retardation in a Less Developed Country: The Case of Sri Lanka, 1951-1976" World Development, $10(9): 829-40$.

Khatkhate. Deena (1988) "Assessing the Impact of Interest Rates in Less Developed Countries," World Development, 16(5): 577-88.

Kim, Joong-Woong (1986) "Economic Development and Financial Liberalization in the Republic of Korea: Policy Reforms and Future Prospects," in $M$. Urrutia (ed.) Financial Liberalization and the Internal structure of Capital Markets in Asia and Latin America. Tokyo: United Nations University, 137-71.

Koshaka. Akira (1984) "The High Interest Rate Policy Under Financial Repression" Developing Economies. 22(4): 41952.

Krueger. Anne 0. (1983) Alternative Trade Strategies and Employment, Vol 3 : Synthesis and Conclusions. Chicago: Chicago University Press.

Krueger. Anne O. (1984) "Problems of Liloralization" in A. C. Harberger ed. world Economic Growth. San Fran isco. Cal: ICS Press. 
Krueger, Anne O. (1985) "How to Liberalize a Small Open Economy" in $M$. Connolly and J. McDermott eds. The Economics of the Caribbean Basin, New York: Praeger.

La1, Deepak and Sarath Rajapatirana (1989) Impediments to Trade Liberalization in Sri Lanka. Thames Essay No. 51, Aldershot: Gower for the Trade Policy Research Centre.

Lamberte, Mario B. (1988) "Financial Liberalization and The International Structure of Capital Markets: The Philippine Case" in M. Urrutia ed. Financial Liberalization and the Internal Structure of Capital Markets in Asia and Latin America, Tokyo: United Nations University, 201-67.

Lee, J. (1987) Improving Domestic Resource Mobilization Through Financial Development: Sri Lanka, Manila: Asian Development Bank.

Lindren, C. J., S. P. Leite, J. Hanson and P. Hayward (1986) Sri Lanka: Financial Policy Issues, Washington, DC: IMF (mimeo).

Little, Ian M., Dipak Mazumdar and John M. Page, Jr. (1987) Small Manufacturing Enterprises: A Comparative Analysis of India and Other Economies, New York: Oxford University Press.

Malhotra, S. R. N. (1984) "The Role of Banking in rural Development" Occasional Paper No. 14, Colombo: Central Bank of Sri Lanka.

Malhotra, V. P. (1989) Report on Sri Lanka Rural Credit Project, Vol. 1 \& 2, Colombo: Central Bank of Sri Lanka.

McKinnon, Ronald (1973) Money and Capital in Economic Development, Washington, DC: Brooking Institution.

McKinnon, Ronald I. (1976) "Savings Propensities and the Korean Monetary Reform in Retrospect" in K. I. McKinnon (ed.) Money and Finance in Economic Growth and Development: Essays in Honor of Edward S. Shaw, New York: Marcel Dekker INC.

McKinnon, Ronald E. (1981) "Financial Repression and Liberalization Problem within Less-Developed Countries" in S. Grassman and E. Lundberg. The World Economic Order: Past and Prospects, London: Macmillan, 365-86.

Mckinnon, Ronald I. (1982) "The Order of Economin Lileralization: Lesscns from Chile and Argentina" in K. Erunner and A. Meltzer (ed.). Economic Liberalization in a World of Change. Amsterdam: North Holland.

McKinnon. Ronald I. (1989) "Financial Libulalization and Eccnomic Development: A Reassessment bf Intwist Rate Policies in Asia and Lat in America" Oxford Review of E..nnomi. Folio. 5(4): $20-54$.

Marga Institute (1978) Tho Informal so+ (N) Notombe city (sri Lanka): Geneva: ILO. 
Marga Institute (1981) "Informal Sector Without Migration: the Case of Colombo" in S. V. Sethuraman (ed.). The Urban Informal Sector in Developing Countries: Employment, Poverty and Environment, Geneva: ILO, 101-8.

Michaely, Michael, Demetrios Papageorgious and Armeane Choksi (forthcoming) Liberalizing Foreign Trade: Lessons of Experience in the Developing World, Oxford: Basil Blackwell.

Narasimham, M. (1983) "Banks and Agricultural Credit: The Indian Experience, Occasional Paper No. 11, Colombo Central Bank of Sri Lanka.

Onis, 2iya and James Riedel (1989) Macroeconomic Crises and Long-term Growth in Turkey, Washington, DC, World Bank (Economic Advisory Service, unpublished manuscript).

Rajapatirana, Sarath (1988) "Foreign Trade and Economic Development: Sri Lanka's Experience" World Development, 16(10):1143-57.

Roe. Allan R. (1982) "High Interest Rates: A New Conventional Wisdom for Development Policy? Some Conclusions from Sri Lankan Experience" World Development, 10(3): 211-22.

Roe, Allan R. (1989) "Interest Rate Policy, Employment and INcome Distribution" in G. T. Renshaw ed. Market Liberalization Equity and Development, Geneva: ILO, 71-103.

Sanderatne. Nimal (1988) "Interest Rate Policy for Rural Lending in Sri Lanka," Upanati--Journal of the Sri Lanka Association of Economists, $3(1): \quad 47-60$.

Sanderatne, Nimal (1989) "The Nature of the Rural Informal Credit Market in Sri Lanka, Center for Policy Studies, Colombo (mimeo).

Saracoglu, Rusdu (1987) "Economic Stabilization and Structural Adjustment: the Case of Turkey" in V. Corbo, M. Goldstein and M. Khan (eds) Growth-Oriented Adjustment Programs, Washington, DC: IMF and World Bank.

Shaw, Edward (1973) Financial Deepening in Economic Development, Oxford: Oxford University Press.

Taylor, Lance (1983) Structuralist Macroeconomics, Applicable Models for the Third WORLD, New York: Basil Books.

Taylor, Lance (1988) Varieties of Stabilization Experience: Towards Sensible Macroeconomics in the Third Worlu. Oxford. Clarendon Press.

Warr. Peter G. (1986) "Indonesia's Other Dutch Disease: Economic Effects of the Petrcleum Bocm". in J. P. Noat* and $S$. Van Wijnbergen (eds) Natural Rescurces and the Marnow ny. 'xtord. Easil Blackwell. 
Wirasinghe, Augustus 0. (1981) "Mobilization of Personal Savings in Sri Lanka: Behavior of Savers and Its Policy Implications" in United Nations, Savings for Development, New York: UN.

Van Wijnbergen, S. (1982) Stagflationary Effects of Monetary Stabilization Policies: A Quantitative Analysis of South Korea" Journal of Development Economics, 10(2):133-69.

Van Wijnbergen, S. (1983) "Credit Policy, Inflation and Growth in a Financially Repressed Economy", Journal of Development Economics. $13(1): 45-65$.

Yusuf, Shahid and R. Kyle Peters (1984) "Saving Behavior and Its Implications for Domestic Resource Mobilization: The Case of the Republic of Korea", World Bank S aff Working Papers, No. 628 , Washington, D.C.: World Bank. 
Data Appendix

The data series used in this study, unless otherwise stated in the text and notes to tables, have been directly obtained or compiled from the following publications of the Central Bank of Sri Lanka:

1. Monthly Bulletin of Statistics

2. Annual Report of the Monetary Board (to the Minister of Finance)

3. Review of the Economy

Data on the organized financial sector is commonly considered as the most reliable of national economic statistics of Sri Lanka.

In the selection and transformation of most of the required data series, we hive simply followed established practices in this field of research.. However, the choice of the price index for measuring the real return of money, real income variable and the construction of gross domestic saving series need some explanatica.

Mckinnon (1973: 96-7; 1989: 35) has forcefully argued that, in measuring the real return on money, the wholesale price index (WPI), which represents claims on a broad basket of tradable goods, is a better deflator than the consumer price index (CPI), which has a large service component. Tangible goods including inventories of commodities of all kinds is the principal alternative asset open to savers, which may be either substitutable or complementary to real money balances. Pure services cannot he "held" in asset portfolios; even households that save with the ultimate intention of consuming services in the distant future must hold those savings in the form of either goods or financial assets.

The WPI of Sri Lanka (compiled by the Central Bank) dates only from 1974 and, therefore, does not cover the full sample period used for the empirical analysis of this study. We therefore choose to use the implicit deflator for the commodity production sectors of the economy derived from national accounts as our price index. This is the best available indicator of tradable-goods prices covering the whole sample period.

The aggregate income variable we used is GDP as measured from the expendicure side. For the period since about 1982 there is a considerable and widening (and yet unexplained) difference between the GDP series derived from the expenditure side and that derived from the production side. We use the former series because there are reasons to suspect that the latter may have overstated the level of eccnomic activity (Jayawardena et al 1987:4). As a part of a major revision into national accounts (following the trade liberalization reforms) in 1978. estimates dating back to 1970 were adjusted for exchange rato hangos and changes in subsidized prices of certain commodities (see Central Banl. Review of the Economy-1978 . lp. $22-23 \mathrm{for}$ details). We adjusted the national expenditure series lack to las? following the same procedure.

In the ahsence of dicert ostimatos. wo pstimated gross domestic savings $1, \%$ sultractine foreign saving (proxiol $\%$ the lalance in the goods and

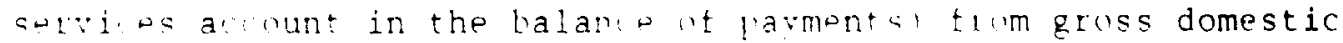
inves ment.. A major limitation involved in this procedure is that 
Inaccuracies in elther serles may lead to measurement errors in the saving estimate. However, if the biases are consistent over time and the errors are random, the use of this series in the analysis of saving behavior need not necessarily yleld misleading results. In any case, the gross domestic savings series is not central to the emplrical analysis of this study. 
Table 1

Distribution of Bank Brancines and Deposits

$\begin{array}{llllll}1965 & 1970 & 1977 & 1979 & 1981 & 1984\end{array}$

\section{Sri Lankan Banksa}

$\begin{array}{lrrrrrr}\text { a. number of branches } & 81 & 152 & 707 & 779 & 915 & 623 \\ \text { b. share of total deposits } & 66 & 76 & 88 & 89 & 84 & 77 \\ & (56) & (72) & (82) & (81) & (72) & (68)\end{array}$

Foreign Banks ${ }^{C}$

Total
a. number of branches
97
165
715

810
936
648
b. total deposits (Rs. Mn.)
1,564
2,394
6,793
2,343
21,403
39,938

Notes: a. Excluding Agricultural Service Centre branches.

b. Total deposit share of state-owned banks in parentheses.

c. Figures in parentheses relate to banks established after 1976.

Source: Central Bank. Annual Report and Review of the Economy (various issues) 
Financial Market Institutions: Percentage Distribution of Assets

1. Commercial Banks ${ }^{a}$

2. Other Deposit Taking Institutions

FCBUS

National Savings Bank

Finance Companies ${ }^{b}$

$\hat{m}$

3. Development Finance Institutions
$1965 \quad 1970 \quad 1977 \quad 1981 \quad 1984$

$\begin{array}{lllll}48.7 & 51.5 & 58.8 & 62.4 & 57.3\end{array}$

$\begin{array}{lllll}18.4 & 21.5 & 17.8 & 16.4 & 21.3\end{array}$

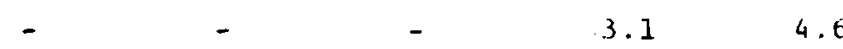

$\begin{array}{lllll}18.4 & 19.3 & 16.0 & 11.6 & 13.0\end{array}$

$\begin{array}{lllll}\text { n.a. } & 2.2 & 1.9 & 1.7 & 3.7\end{array}$

$\begin{array}{llll}2.8 & 1.3 & 3.1 & 3.1\end{array}$

National Development Bank ${ }^{C}$

Development Finance Corporation

4. Nonbank Financial Institutions

State-owned provident funds

State-owned insurance companies

5. Total

(Rs. Million)

$\begin{array}{lllll}0.8 & 1.0 & 0.7 & 1.9 & 1.7\end{array}$

$\begin{array}{lllll}29.2 & 24.2 & 22.1 & 18.1 & 18.3\end{array}$

$\begin{array}{lllll}18.9 & 17.6 & 15.2 & 12.2 & 12.4\end{array}$

$\begin{array}{lllll}0.9 & 1.2 & 2.3 & 1.98 & 1.2\end{array}$

$\begin{array}{lllll}100 & 100 & 100 & 100 & 100\end{array}$

$\begin{array}{lllll}3.718 & 6.212 & 17.217 & 50.598 & 95.901\end{array}$

Notes: a. Excluding Foreign Currency Banking Units (FCBUs).

b. This figure relates to only those companies which report their assets to the Central Banks.

c. Figures for 1965 and 1970 show the combined deposits of Post Office Savings Bank. Ceylon Savings Bank and the Savings Certificate Fund which were analgamated in 1973 tc form the NSB.

Source: Khatkhate (1980) supplemented with various issues of Central Bank. Monthly Bulletin of Statistics. 
Table 3

Real Exchange Rate Index ${ }^{2}, 1965-83$

$(1980=100)$

\section{Exportables}

Total Non-traditional Importables

$\begin{array}{rrrr}1965-69 b & 48 & 29 & \\ 1970-75^{b} & 52 & 48 & \\ 76 & 66 & 62 & 72 \\ 77 & 82 & 81 & 84 \\ 78 & 94 & 80 & 91 \\ 79 & 97 & 84 & 100 \\ 80 & 100 & 100 & 98 \\ 81 & 95 & 100 & 95 \\ 82 & 85 & 81 & 99 \\ 83 & 86 & 78 & \end{array}$

Notes: a. Export/import unit value index in rupees (adjusted for trade taxes and subsidies) deflated by the implicit GDP deflator for nontradable (construction and services) sectors.

b. Not available

c. Annual averages

Source: Cuthbertson and Athukorala (1988) 
Table 4

Interest Rates, 1965-87

Commercial Bank

Commercial Bank

NSB Deposit Rate

Deposit Rate

Lending Rate

$\begin{array}{rr}1965-70 & 3.7(-2.4) \\ 1971-76 & 7.2(-8.4) \\ 1977-83 & 14.9(1.3) \\ 1984-87 & 14.2(5.2) \\ 1977 & 11.1(8.1) \\ 1978 & 12.6(2.3) \\ 1979 & 12.1(-5.1) \\ 1980 & 17.0(2.3) \\ 1981 & 17.2(0.3) \\ 1982 & 17.8(-5.1) \\ 1983 & 16.5(5.1) \\ 1984 & 16.7(4.6) \\ 1985 & 14.3(3.3) \\ 1986 & 12.8(8.1) \\ 1987 & 12.8(4.8)\end{array}$

$3.7(-2.4)$

$9.0(-2.9)$

$5.0(-11.1)$

$8.5(-7.1)$

$13.8(0.2)$

$16.3(2.5)$

$9.8(0.1)$

$20.2(12.9)$

$10.6(7.7)$

$11.3(8.4)$

$11.4(1.1)$

$12.8(1.5)$

$11.8(-5.3)$

$17.5(2.9)$

$13.8(-3.2)$

$17.8(1.0)$

$17.2(2.6)$

$8.4(1.6)$

$13.6(-9.3)$

$20.0(-2.9)$

$14.1(2.7)$

$20.6(9.2)$

$12.6(0.5)$

$20.5(8.4)$

$11.2(0.2)$

$20.1(9.1)$

$7.5(0.3)$

$20.3(13.1)$

$7.4(-0.5)$

$19.8(11.9)$

Notes: a. In each column, the first figure indicates the nominal rate and the second (bracketed) figure the real rate. Defosit rate is the weighted average of savings deposit and 1-year fixed deposit rates. Lending rate is the weighted average rates of loans classified by securities. Real rate is the difference between the current nominal rate and the inflation rate as measured by the GDP deflator (non-services) for the previous year.

b. Annual average

Source: Columns 1 and 2: compiled using data from Central Bank, Review of the Economy. Column 3, Central Bank. Bulletin. 
Table 5

Gross Domestic Product: Sectoral Composition and Growth Ratesa at Constant (1970) Factor Costs (annual averages), 1970-85

$1970-77 \quad 1980-83 \quad 1984-85$

\section{Sector}

$\begin{array}{cccc}\text { Primary products } & 36.6 & 24.8 & 28.2 \\ \text { export agricultureb } & (2.1) & (4.1) & (4.8) \\ \text { domestic agriculture } & 17.0 & 10.2 & 9.3 \\ & (-1.7) & (0.5) & (1.3) \\ \text { Industry } & 17.5 & 11.8 & 14.7 \\ & (3.5) & (5.3) & (9.5) \\ \text { construction } & 16.5 & 19.0 & 21.2 \\ \text { manufacturingc } & (1.0) & (4.2) & 5.8 \\ & 4.9 & 4.8 & (1.3) \\ & (-2.6) & (8.8) & 12.2 \\ \text { Services } & 9.1 & 9.7 & (7.8) \\ & (2.3) & (6.4) & 50.6 \\ \text { Total GDP } & 46.7 & 56.2 & (5.5)\end{array}$

Source: Central Bank, Review of the Economy (various issues). 
Table 6

The Behavior of the Financial Sector:

Selected Indicators, 1960-87

$\begin{array}{cccccc}M 1 * & M 2 * & M 3 * & M 1 / G D P & M 2 / G D P & M 3 / G D P \\ 1980=100 & 1980=100 & 1980=100 & z & z & z\end{array}$

$\begin{array}{lrrrrrr}1960 & 61 & 37 & 37 & 17 & 22 & 29 \\ 1965 & 87 & 55 & 53 & 20 & 26 & 33 \\ 1970 & 83 & 65 & 62 & 14 & 22 & 29 \\ 1975 & 59 & 43 & 47 & 12 & 17 & 25 \\ 1977 & 69 & 54 & 55 & 15 & 24 & 32 \\ 1978 & 82 & 71 & 73 & 14 & 26 & 34 \\ 1979 & 94 & 87 & 89 & 15 & 29 & 38 \\ 1980 & 100 & 100 & 100 & 14 & 30 & 38 \\ 1981 & 96 & 109 & 108 & 12 & 31 & 40 \\ 1982 & 107 & 131 & 133 & 12 & 31 & 40 \\ 1983 & 116 & 137 & 141 & 12 & 31 & 40 \\ 1984 & 113 & 138 & 145 & 10 & 28 & 38 \\ 1985 & 127 & 154 & 165 & 12 & 30 & 41 \\ 1986 & 136 & 154 & 168 & 12 & 28 & 40 \\ 1987 & 146 & 161 & 174 & 13 & 30 & 41\end{array}$

* At constant (1980) prices

Source and method of compilation: see Data Appendix 
Table 7

Demand for Financial Assets: Regression Results, 1960-1987

M1 STD

\begin{tabular}{|c|c|c|}
\hline Constant & $\begin{array}{l}2.74 * \\
(7.29)\end{array}$ & $\begin{array}{c}-3.39 * \star \\
(2.78)\end{array}$ \\
\hline GDP & $\begin{array}{l}0.45 \star \star \\
(4.71)\end{array}$ & $\begin{array}{l}1.55 * \star \\
(4.59)\end{array}$ \\
\hline$(1+$ RSTD $)$ & $\begin{array}{r}-2.08 * \star \\
(2.45)\end{array}$ & $\begin{array}{l}6.13^{\star} \\
(2.23)\end{array}$ \\
\hline$D *(1+R S T D)$ & $\begin{array}{c}1.32 \\
(1.79)\end{array}$ & $\begin{array}{l}-1.99 \\
(0.83)\end{array}$ \\
\hline$(1+P E)$ & $\begin{array}{r}-4.18 * * \\
(3.69)\end{array}$ & $\begin{array}{c}5.84 \\
(1.59)\end{array}$ \\
\hline$D *(1+P E)$ & $\begin{array}{l}2.65 \star \star \\
(3.14)\end{array}$ & $\begin{array}{l}-0.45 \\
(0.16)\end{array}$ \\
\hline Test Statistics & & \\
\hline $\bar{R}^{2}$ & 0.77 & 0.84 \\
\hline $\mathbf{F}$ & 18.43 & 30.22 \\
\hline DW & 1.61 & 1.60 \\
\hline LM & $2.21 \#$ & 0.73 \\
\hline RESET 2 & 0.88 & $3.46 \%$ \\
\hline $\mathrm{JB}$ & $1.54 \#$ & 0.85 \\
\hline WH & $0.08 *$ & 0.15 \\
\hline
\end{tabular}

Variables: $M 1$ = currency and demand deposits (real) held by the non-bank private sector; STD = savings and time deposits (real) held by the non-bank private sector; GDP = real GDP; RITN = weighted average real interest rate on savings and time deposits; $P E=$ rate of inflation with a one-year lag; $D=$ trade liberalization dumy ( 1 for 1978-87 and zero for other years)

Notes: $\quad t$ - ratios of coefficients are given in parentheses with the level of significance denoted as, $\star *=$ significant at the one percent level, and * = significant at the five percent level.

LM Lagrange multiplier test of seriel correlation. F version.

RESET2 Ramsey's RESET test for functional form misspecification using the square of the fitted values. F version.

JB Jarque-Bera test for the normality of residuals.

WH White's heteroscedasticity test. $F$ version.

\# Null hypothesis is not rejerted at the five percent level.

\# Null hypothes is is not rejected at the one percent level.

Data sources and the methodology used in constructing the data series are discussed in the Data Appendix. 
Table 8

Grose Domestic Saring, 1965-1984

TDS/GDP

(7)
PRS / GDP

(z)

11.9

12.5

14.2

16.5

13.4

14.8

13.4

12.2

13.7

16.1
PRS/YPR

(z)

1977

1979

1981

1982

1983

1984

12.7

11.8

13.8

19.9
14.8

14.4

21.1

23.4

18.7

22.7

18.1

18.1

18.1

21.4

TDS = gross domestic saving

PRS = gross domestic private saving

$Y P R=$ private-sector income (proxied, GDP + (government revenue - transfers to private sector current accounts)).

Source and method of compilation: see Data Appendix 
Table 9

Composition of Net Assets of Households, 1973, 1978/79 and 1981/32

$$
\text { (percentage shares of total) }
$$

$$
1966 / 70 \quad 1972 / 73 \quad 1978 / 79 \quad 1981 / 82
$$

\begin{tabular}{|c|c|c|c|c|}
\hline Financial Assets & 23.8 & 29.4 & 34.2 & 54.3 \\
\hline Bank depositsa & 9.6 & 9.3 & 5.7 & 33.2 \\
\hline Other claims $b$ & 15.2 & 20.1 & 28.4 & 21.1 \\
\hline Physical Assets & 76.2 & 70.4 & 65.8 & 45.7 \\
\hline Land and buildings & 49.2 & 46.5 & 34.5 & 27.4 \\
\hline $\begin{array}{l}\text { Business and industrial } \\
\text { ventures } c\end{array}$ & 27.0 & 23.9 & 31.3 & 18.3 \\
\hline & 100 & 100 & 100 & 100 \\
\hline
\end{tabular}

Notes: a. Does not include current account balances, but includes government bonds, securities and shares. In 1981/82 the latter three items together accounted for less than one percent of total financial assets.

b. Contributions to provident funds, loans given and contributions to informal saving schemes (Cheetus).

c. Including purchase of machinery and equipment and business vehicles.

Source: Saito (1976) (estimates for 1966/70) and Central Bank, Consumer Finance and Socio-economic Survey, $1973,1978-79$ and $1981-2$. 
Table 10

Determinants of Real Exchange Rate (RER): Regression Results, 1970-1987

(1)

$$
\begin{gathered}
1.32 \\
(5.67) \\
-0.03 \\
(0.32)
\end{gathered}
$$

TOT

NFC

GEXP

FIR

$D$ *FIR

BMP

Test statistics

$\overline{\mathrm{r}}$

$\vec{F}$

DW

LM

RESET2

JB

WH

Variables: TOT terms of trade $(1980=1.0)$

NFC net foreign capital inflow as a ratio of GNP

GEXP total government expenditure as a ratio of gross national expenditure

FIR financial intermediation ratio (M3/GNP)

$D \star F I R$ slope dummy for FIR where $D$ takes 1 for 1978-87 and 0 otherwise

BMP black market premium on the official exchange rate

Notes: $\quad t$-ratios of coefficients are given in parentheses with the level of significance denoted as $* \star=$ one percent level and $\star=$ five percent level. For definitions of test statistics see Table 7 .

Data sources and method of compilation of data series are explained in the Data Appendix. 
Table 11

Total Credit Extended by Financlal Institutions, 1977*-85

\begin{tabular}{|c|c|c|c|c|c|c|}
\hline & & 1977 & 1979 & 1981 & 1983 & 1985 \\
\hline 1. & Total Credit Rs. mnb & 25361 & 25669 & 33990 & 43963 & 47798 \\
\hline & 1.1 Government, net (z) & 49.1 & 40.7 & 33.0 & 32.5 & 32.0 \\
\hline & 1.2 Public Corporations (z) & 13.4 & 15.1 & 12.3 & 7.3 & 6.0 \\
\hline & 1.3 Co-operatives $(x)$ & 10.0 & 8.7 & 3.5 & 3.1 & 1.8 \\
\hline & 1.4 Private Sector ( 2$)$ & 27.5 & 35.5 & 31.2 & 57.1 & 60.2 \\
\hline & & 100 & 100 & 100 & 100 & 100 \\
\hline & net, Rs. mb & 7426 & 10465 & 11241 & 14331 & 15291 \\
\hline & Commercial Banks ( $z)$ & 0.7 & -2.3 & 0.5 & -0.9 & -1.9 \\
\hline & National Savings Bank (z) & 40.9 & 46.7 & 44.7 & 31.7 & $\$ 7.9$ \\
\hline & Employee Provident Fund $(z)$ & 40.7 & 43.1 & 46.2 & 45.8 & 56.7 \\
\hline & Insurance Companies ( $z$ ) & 16.6 & 14.6 & 12.2 & 7.0 & 6.2 \\
\hline & & -1.1 & -2.1 & -3.6 & -3.6 & -16.9 \\
\hline
\end{tabular}

Notes: a. Other than the Central Bank.

b. At 1980 priçes.

Source: Central Bank, Review of the Econony, (varlous lsoues). 
Table 12

Commercial Bank Lendinga, 1970-85

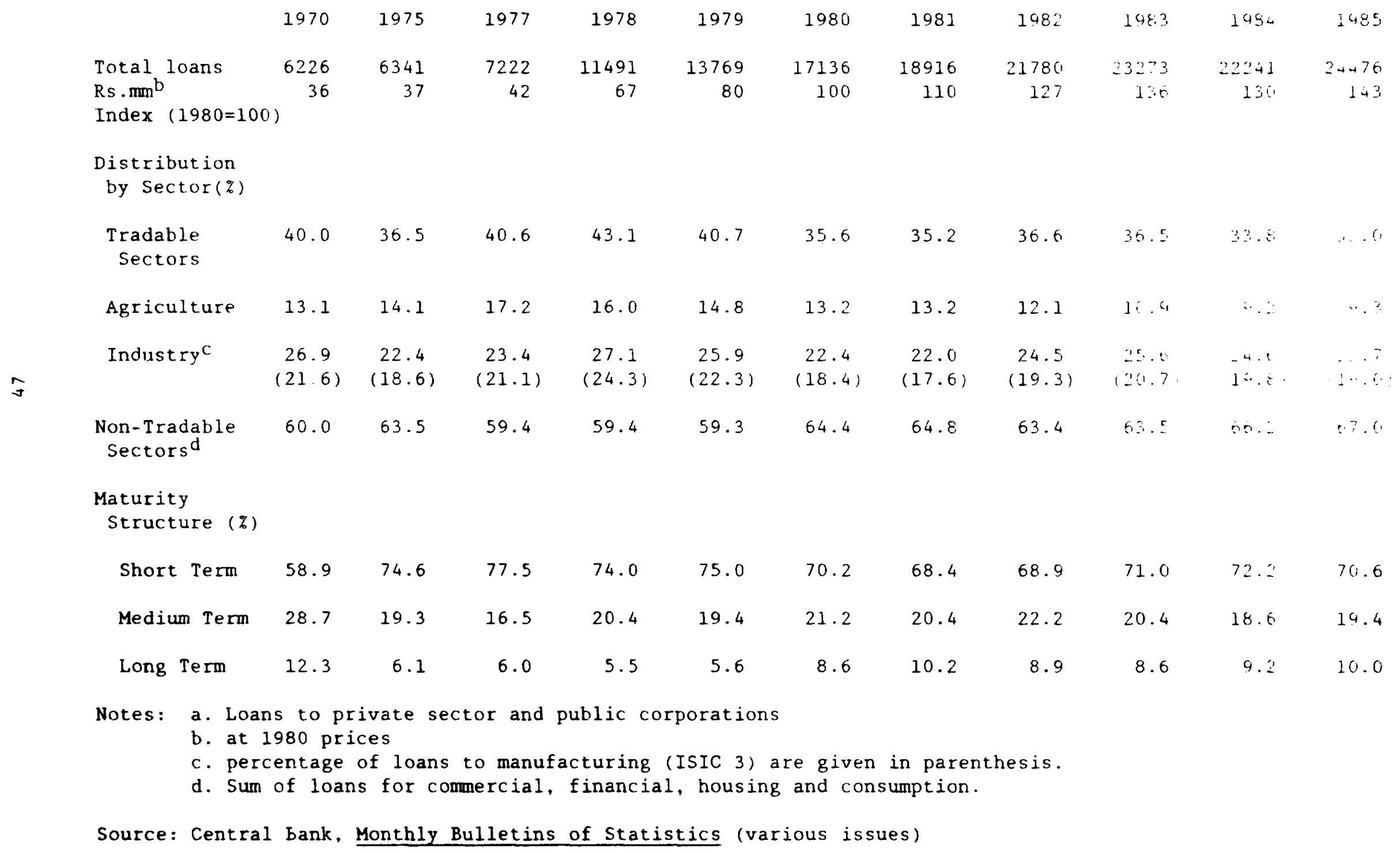


Table 13

Medium and Long Term Credit Extended by

Commercial Banks and Development Finance Institutions (DFI)

DFI Share

Total Loans*

in $\operatorname{tota} 1(x)$

Rs. $m$ Index

$1980=100$

1970

2979

52

9.6

1975

1885

33

18.6

1977

1967

34

15.4

1978

3477

61

11.5

1979

4125

72

15.5

1980

5727

100

10.7

1981

7012

122

13.9

1982

7551

132

16.2

1983

8249

144

15.9

1984

7935

139

19.7

1985

9636

168

22.6

Notes: *At 1980 prices.

Source: Central Bank, Monthly Bulletin of Statistics, (various issues). 
Table 14

Commercial Bank Credit to Manufacturing by ISIC Subdivisions, 1973-85 (percentage distribution)*

\begin{tabular}{|c|c|c|c|c|c|c|}
\hline & & 1973 & 1977 & 1980 & 1983 & 1985 \\
\hline (1) & $\begin{array}{l}\text { Food, beverages } \\
\text { and tobacco }\end{array}$ & $\begin{array}{l}2.7 \\
(0.2)\end{array}$ & $\begin{array}{l}4.4 \\
(2.3)\end{array}$ & $\begin{array}{c}9.5 \\
(1.4)\end{array}$ & $\begin{array}{l}8.9 \\
(2.4)\end{array}$ & $\begin{array}{l}7.5 \\
(0.3)\end{array}$ \\
\hline (2) & $\begin{array}{l}\text { Textiles } \\
(4.5)\end{array}$ & $\begin{array}{l}18.2 \\
(11.9)\end{array}$ & $\begin{array}{l}25.5 \\
(13.3)\end{array}$ & $\begin{array}{l}25.8 \\
(2.7)\end{array}$ & $\begin{array}{c}28.9 \\
(10.5)\end{array}$ & 29.3 \\
\hline (3) & $\begin{array}{l}\text { Wearing apparel } \\
\text { and leather }\end{array}$ & $\begin{array}{l}5.8 \\
(1.5)\end{array}$ & $\begin{array}{l}5.8 \\
(0.3)\end{array}$ & $\begin{array}{l}15.1 \\
(1.1)\end{array}$ & $\begin{array}{l}3.7 \\
(0.7)\end{array}$ & $\begin{array}{l}4.5 \\
(1.4)\end{array}$ \\
\hline (4) & $\begin{array}{l}\text { Wood and wood } \\
\text { products }\end{array}$ & $\begin{array}{l}2.9 \\
(2.4)\end{array}$ & $\begin{array}{l}0.7 \\
(0.2)\end{array}$ & $\begin{array}{l}0.7 \\
(0.1)\end{array}$ & $(-)^{0.9}$ & $\begin{array}{l}1.4 \\
(0.5)\end{array}$ \\
\hline (5) & $\begin{array}{l}\text { Paper and paper } \\
\text { products }\end{array}$ & $\begin{array}{l}5.1 \\
(3.6)\end{array}$ & $\begin{array}{l}3.3 \\
(1.7)\end{array}$ & $\begin{array}{l}3.1 \\
(0.9)\end{array}$ & $\begin{array}{l}2.8 \\
(0.2)\end{array}$ & $(-)^{3.9}$ \\
\hline (6) & $\begin{array}{l}\text { Rubber and plastic } \\
\text { products }\end{array}$ & $\begin{array}{l}4.7 \\
(0.5)\end{array}$ & $(-)^{1.8}$ & $\begin{array}{l}4.6 \\
(0.1)\end{array}$ & $(-)^{3.9}$ & $(-)^{4.3}$ \\
\hline (7) & $\begin{array}{l}\text { Chemical, petroleum } \\
\text { and coal }\end{array}$ & $\begin{array}{c}8.7 \\
(4.0)\end{array}$ & $\begin{array}{l}32.7 \\
(31.1)\end{array}$ & $\begin{array}{l}6.3 \\
(2.7)\end{array}$ & $\begin{array}{l}5.6 \\
(0.4)\end{array}$ & $\begin{array}{l}5.4 \\
(? .5)\end{array}$ \\
\hline (8) & $\begin{array}{l}\text { Non-metallic mineral } \\
\text { products }\end{array}$ & $\begin{array}{c}1.1 \\
(0.1)\end{array}$ & $\begin{array}{c}3.1 \\
(1.3)\end{array}$ & $\begin{array}{l}3.7 \\
(1.8)\end{array}$ & $\begin{array}{l}5.4 \\
(2.6)\end{array}$ & $\begin{array}{l}3.7 \\
(2.4)\end{array}$ \\
\hline (9) & $\begin{array}{l}\text { Basic metal } \\
\text { products }\end{array}$ & $\begin{array}{c}6.0 \\
(3.2)\end{array}$ & $\begin{array}{l}7.1 \\
(5.3)\end{array}$ & $\begin{array}{l}8.0 \\
(3.1)\end{array}$ & $\begin{array}{l}7.1 \\
(2.0)\end{array}$ & $\begin{array}{l}3.4 \\
(1.6)\end{array}$ \\
\hline (10) & $\begin{array}{l}\text { Fabricated metal } \\
\text { products, machinery } \\
\text { and transport } \\
\text { equipment }\end{array}$ & $\begin{array}{c}3.4 \\
(0.9)\end{array}$ & $(-)^{2.2}$ & $\begin{array}{l}6.0 \\
(1.3)\end{array}$ & $\begin{array}{l}2.2 \\
(0.1)\end{array}$ & $(-)^{2.3}$ \\
\hline (11) & $\begin{array}{l}\text { Other } \\
(25.1\end{array}$ & $\begin{array}{l}41.2 \\
(1.9)\end{array}$ & $\begin{array}{l}13.3 \\
(2.2)\end{array}$ & $\begin{array}{l}17.1 \\
(18.4)\end{array}$ & $\begin{array}{c}30.9 \\
(13.7)\end{array}$ & 34.2 \\
\hline Tota & $\begin{array}{l}\text { (Rs. mn) } \\
(481)\end{array}$ & $\begin{array}{l}390 \\
001\end{array}$ & $\begin{array}{r}1253 \\
(890)\end{array}$ & $\begin{array}{r}3163 \\
(1930)\end{array}$ & $\begin{array}{r}6509 \\
(1738)\end{array}$ & 7239 \\
\hline Publ. & $\begin{array}{l}\text { ic-sector share } \\
\text { otal credit }\end{array}$ & 46.1 & $55 . \%$ & 28.1 & 29.7 & 24.0 \\
\hline
\end{tabular}

Notes: * Figures in parentheses relate to credit to public-sector manufacturing ventures.

- Denotes figures less than 0.05 .

Source: Compiled using data from Central Bank of Sri Lanka, Monthly Bulletin (various issues). 
Table 15

Gross Dumestil Fixed Capital Formation

TFO $^{*} \quad$ PFC $^{\times} \mathrm{TFC}$
$(1980=100)(1980=100)$

$\begin{array}{lrrrrr}1955-69 & 29 & 37 & 14.1 & 7.4 & 9.5 \\ 1970-76 & 45 & 62 & 15.5 & 8.6 & 10.2 \\ 1077 & 29 & 46 & 13.8 & 7.2 & 8.5 \\ 1978 & 43 & 52 & 19.9 & 8.9 & 12.6 \\ 1970 & 73 & 92 & 25.2 & 13.1 & 18.4 \\ 1980 & 100 & 190 & 31.2 & 13.7 & 21.0 \\ 1981 & 101 & 113 & 27.3 & 13.0 & 17.5 \\ 1982 & 126 & 145 & 31.9 & 14.7 & 20.0 \\ 1983 & 125 & \text { n.a. } & 31.0 & \text { n.a. } & \text { n.a. } \\ 1984 & 120 & \text { n.a. } & 28.3 & \text { n.a. } & \text { n.a. } \\ 1985 & 118 & \text { n.a. } & 25.9 & \text { n.a. } & \text { n.a. } \\ 1986 & 123 & \text { n.a. } & 25.8 & \text { n.a. } & \text { n.a. } \\ 1987 & 121 & \text { n.a. } & 25.2 & \text { n.a. } & \text { n.a. }\end{array}$

* at 1980 prices.

TFC gross domestic fixed capital formation.

PFC private-sector gross fixed capital formation.

iPR private-sector income (as defined in Table 8 ).

Source and Method of Compilation: see Data appendix. 
Table 16

Return on Capital in the Private Corporate Sector, $1974-83^{2}$

Firm Typeb

$1974-77 \quad 1978 / 79 \quad 1979 / 30 \quad 1980 / 81 \quad 1981 / 82$

$1982 / 83$

1. Manufacturing (14)

28.4

74.4

31.3

79.8

56.8

33.4

48.4

20.8

24.2

48.7

48.5

39.5

26.4

28.1

1.2 Export-oriented (4) $\mathrm{C}$

7.2

48.8

33.3

28.7

30.9

40.3

32.4

2. Trading(10) Trave 1 (5)

12.0

56.6

34.4

22.1

14.7

19.3

30.9

52.6

57.3

4. Total sample(29)

Notes: a. Return on capital is measured as the ratio of pre-tax profits to total estimates related. 29 public limited liability companies are representiative of large corporate sector only.

b. Number of firms included in each category are shown in brackets.

c. Firms with an export share in turnover of more than 50 percent or more. Data for $1974-77$ and $1978 / 79$ relate to two firms only.

Source: Compiled using data from Colomho Brokers Association, Hand Book of Rupee Companies, Colombo (various issues). 
Table 17

Distribution of Household Eorrowing by

Purpose and Source (\%), 1973, $1978 / 9$ and $1981 / 82^{a}$

Purpose of Borruwing Informal (curb market) Sources

F:arancial

Institutions

(1)
Money Lenders

(2) other, with interest ${ }^{c}$

(3)
Without interest $d$

(4)
(-)

15.4

(7.2)

11.4

(7.7)

(8.0)

$(28.1)$

$(19.7)$

$(24.8)$

Houring

$\begin{array}{cc}1973 & - \\ & (-) \\ 1978 / 9 & 48.8 \\ & (44.9) \\ 1981 / 2 & 45.5 \\ & (13.6)\end{array}$

Trade

$\begin{array}{rc}1973 & - \\ & - \\ 1978 / 9 & 15.2 \\ & (2.3) \\ 1981 / 2 & 37.8 \\ & (11.8)\end{array}$

other ${ }^{b}$

$\begin{array}{cc}1973 & - \\ & (-) \\ 1978 / 9 & 9.1 \\ & (21.5) \\ 1981 / 2 & 4.1 \\ & (21.7)\end{array}$

Total

$$
197
$$

$1978 / 9$

$1981 / 2$

8.2

(2.8)

8.7

(5.0)

$$
\begin{gathered}
(-) \\
31.3 \\
(36.3) \\
15.5 \\
(9.0)
\end{gathered}
$$

$$
\begin{gathered}
4.5 \\
(0.3) \\
0.8 \\
(1.2)
\end{gathered}
$$

31.7

$(4.6)$

7.7

(3.4)
$(-)$
9.8
(7.9)
14.7
(14.8)
(-)
10.1
(9.1)
24.3
(10.9)

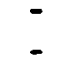

47.3

(7.1)

30.7

(15.7)

(15.1)

(-)

24.8

(4i.7)

50.2

(51.2)

37.3

(-)

20.1

25.3

(100)

40.1

(100.0)
$(100)$

20.8

(100)
(-)

(-)

11.6

(72.0)

7.9

(62.3)

(E6.1)

$$
(-13.0
$$

29.1

(100)

12.1

(100)
29.4

(-)

25.5

(100)

27.0

(100)
Total

(5)

100

(21.7)

100

(12.1)

100

(18.5)

100

(1.9)

100

(12.1)

(-)

100

(23.2)

100

(i2.2) 
Table 17 continued

Notes: a Non-bracketed figures relate to percentage distribution of loans by source. Percentage distribution by purpose is shown by the bracketed figures. " - " denotes figures which are not available. b Borrowing for consumption, ceremonies, settlement of debt and other unclassified borrowings.

c Mainly from boutiques, and employers.

d Mainly from friends and relatives.

e Includes housing loans.

Source: Compiled from Central Bank of Ceylon, Survey of Sri Lanka's Consumer Finances 1973 (Part II), and Report on Consumer Finances and Socioeconomic Survey $1978 / 79$ and $1981 / 82$ (Part II). 
Table 18

Institutional Lending Rates ( $z$ )

Commercial Banks DFC ${ }^{b} \quad$ NDBC

$\begin{array}{lc}\text { Secured } & \text { Unsecured } \\ \text { loansa } & \text { loans }\end{array}$

$\begin{array}{rrrrr}1970 & 6.5-12 & 8.5-12 & 9.5-12 & -- \\ 1975 & 8.5-12 & 9.5-14 & 9.5-12.5 & -- \\ 1976 & 8.5-14 & 9.5-14 & 9.5-12.5 & -- \\ 1977 & 13.0-19 & 18.0-20 & 9.5-13 & -- \\ 1978 & 13.0-19 & 18.0-21 & 10.5-16 & -- \\ 1979 & 13.0-19 & 18.0-21 & 10.5-17 & 10-12 \\ 1980 & 13.0-28 & 19.0-30 & 13.0-17 & 10-17 \\ 1981 & 13.0-28 & 19.0-32 & 12.0-17 & 10-17 \\ 1982 & 16.0-30 & 14.0-30 & 11.0-14 & 10-17 \\ 1983 & 18.0-28 & 11.0-33 & 11.0-14 & 9-14 \\ 1984 & 16.0-30 & 14.0-33 & 11.0-14 & 7-14 \\ 1985 & 11.0-30 & 13.0-30 & 14.0-21 & 7-14 \\ 1986 & 12.0-30 & 10.0-30 & 14.0-28 & 7-14\end{array}$

Notes: a. These rates relates to loans secured by immoveable property. Lending rate for loans based on other types of securites show a similar pattern.

b. Development Finance Corporation.

c. National Development Bank.

Source: Central Bank, Review of the Economy (various issues). 
Table 19

Household Borrowing by Source and Rate of Interest

Ra $e$ of Interest

per annum

Institutional sources Informal sources

Total

per annum

$\begin{array}{lc}0 & 0 \\ 1-10 & 9.0 \\ 11-20 & 22.2 \\ 21-30 & 40.5 \\ 31-40 & 24.8 \\ 41-50 & 0.2 \\ 51-60 & 3.3 \\ 61-100 & 0 \\ \text { over } 101 & 0\end{array}$

100

\begin{tabular}{rrrrr}
\multicolumn{5}{c}{$\begin{array}{l}\text { Other } \\
\text { Money }\end{array}$} \\
0 & 0 & 70.5 & 44.9 & 27.8 \\
9.0 & 1.4 & 3.1 & 2.5 & 4.9 \\
22.2 & 4.1 & 23.6 & 16.5 & 18.7 \\
40.5 & 16.0 & 1.5 & 6.8 & 19.6 \\
24.8 & 4.2 & 0.2 & 1.7 & 20.5 \\
0.2 & 3.4 & 0 & 1.2 & 0.8 \\
3.3 & 5.1 & 0.5 & 2.2 & 1.2 \\
0 & 6.2 & 0.3 & 2.5 & 1.6 \\
0 & 59.6 & 0.3 & 21.7 & 14.9 \\
100 & & & & \\
& 100 & 100 & 100 & 100
\end{tabular}

Source: Central Bank, Report on Consumer Finances and Socioeconomic Survey 1981/82, Part I Colombo, Table 7.18. 


\section{PRE Workina Paoer Series}

Irke

Recent Evidence from Maharashtra's

"Employment Guarantes Scherne"

WPS569 Domestic Purchase Requirements for Wendy 5 . Takacs

Import License Allocations ir, Mali

WPS570 Debt Concentration and Secondary Market Prices

WPS571 Credit's Effect on Productivity in

Chinese Agriculture: A

Microeconomic Model of

Disequilibrium

WPS572 Capital Positions of Japanese

Banks

WPS573 Malaysian Labor Markets iJnder

Structural Adjustment

WPS574 Public Policeses and Saving in:

Developing Countries

WPS575 Household Saving in Developing

Countries: First Cress-Ccuntry

Evidence

WPS576 Lessonsfrom Tax Retorm:

An Overview

WPS577 Atrica's Rising Inflation: Causes, Consequences, and Cures

WPS578 The Bank's Use of Technical

Assistance for Institutional

Development

WPS579 Chile's Experience with Stabilization Revisited

WPS580 Do Natural Resource-Based Industrialization Strategies Convey Important (Unrecognized) Price Benefits for Commodity-Exporting Developing Countries?
Author

Martin Ravallion

Gaurav Datt

Shubham Chaudhuri

Raquel Fernandez

Sule Ozler

Contact

tor oaper

Late

January 1991

C. Spooner 30464

January 1991

S. Falion 37947

January 1991

S. King-Watson 31047

Gershon Feder

Lawrence J. Lau

Justin $Y$. Lin

Xiaopeng Luo

Edward J. Kane

Haluk Unal

January 1991

S. King-Watson 33730

Asli Demirguc-Kunt

Dipak Mazumdar

January 1991

M. Schreier 36432

Vittorio Corbo

January $1 \leqq 91$

S. Jonnakuty 39074

Klaus Schmidt-Heboel

Steven B. Webo

Giancarlo Corsetti

Wayne Thirsk

January 1991

A. Bhalla 37699

Ajay Chinibber

February 1991

B. Dhomun 39413

Beatrice Buyck

January 1991

E. Madrona 37496

Vittorio Corbo

Andrés Solimano

January 1991

E. Khine 39361

Alexander J. Yeats

January 1991

J. Jacnbson 33710 
Ith

WPS581 How Successful is World Bank Lending for Structural Adjustment?

WPS582 Adjustment Programs and Bank Support: Rationale and Main Results

WPS583 World Bank Lending for Education Research, 1982-89

WPS584 Whither Hungary and the European Communities?

WPS585 Financial Innovation and Money Demand: Theory and Empirical Implementation
Fobruary 1991

Medium-Sized Enterprises: An

Empirical Assessment

WPS589 To Prescribe or Not to Prescribe:

On the Regulation of Pharmaceuticals

in Developing Countries

WPS590 The Domestic Financial Market and the Trade Liberalization Outcome:

The Evidence from Sri Lanka

WPS591 Global Indicators of Nutritional Risk
Author

Patrick Conway

Vittorio Corbo

Stanley Fischer

Marlaine E. Lockheed

Alastair G. Rodd

Alfred Tovias

Sam Laird

Patricio Arrau

Jose de Gregorio
Date

January 1991

January 1991

January 1991

January 1991

January 1991

February 1991

Martin Ravalion

Gaurav Datt

Dominique van de Walle

Elaine Chan

Brian Levy

Rae Galloway

Asli Demirgüç-Kunt

Harry Huizinga

Contact

foroaper

S. Fallon

37947

L. Oropesa

39075

C. Cristobal 33640

G. Ilogon 33732

S. King-Watson 31047

WDR Office 31393

WDR Otfice 31393

February 1991

E. Madrona 37496

February 1991

O. Nadora S6-065

M. Kienzle

30733

Sarath Rajapatirana

February 1991

February 1991

O. Nadora 31091

February 1991

S. King-Watson 33730 